\title{
Consequence Analyses Following Potential Savannah River Site Hydrological Releases (U)
}

D.R. Marx, T.I. Brown Jr., J.M. Thompson

April 1998

Classification

UNCLASSIFIED

DOES NOT CONTAIN

UNCLASSIFIED CONTROLLED

NUCLEAR INFORMATION
ADC \&

Reviewing

Official:

K.R. O'Kula, Managing Member, Con sequenes Analysis

Date:
Westinghouse Savannah River Company Aiken, SC 29808

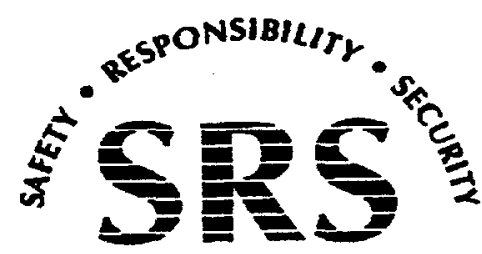

SAVANNAH RIVER SITE

PREPARED FOR THE U.S. DEPARTMENT OF ENERGY UNDER CONTRACT NO. DE-AC09-96SR18500 
Keywords:

Waterborne Release

Emergency Planning

Consequence Analysis

Hydrological Models

\section{Consequence Analyses Following Potential Savannah River Site Hydrological Releases (U)}

D.R. Marx, T.I. Brown Jr., J.M. Thompson

April 1999

Westinghouse Savannah River Company Aiken, SC 29808

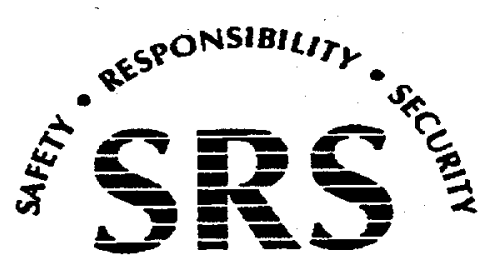

SAVANNAH RIVER SITE

PREPARED FOR THE U.S. DEPARTMENT OF ENERGY UNDER CONTRACT NO. DE-AC09-96SR18500 


\section{DISCLAIMER}

This report was prepared as an account of work sponsored by an agency of the United States Government. Neither the United States Government nor any agency thereof, nor any of their employees, makes any warranty, express or implied, or assumes any legal liability or responsibility for the accuracy, completeness, or usefulness of any information, apparatus, product, or process disclosed, or represents that its use would not infringe privately owned rights. Reference herein to any specific commercial product, process, or service by trade name, trademark, manufacturer, or otherwise does not necessarily constitute or imply its endorsement, recommendation, or favoring by the United States Government or any agency thereof. The views and opinions of authors expressed herein do not necessarily state or reflect those of the United States Government or any agency thereof.

This report has been reproduced directly from the best available copy.

Available to DOE and DOE contractors from the Office of Scientific and Technical Information, P.O. Box 62, Oak Ridge, TN 37831; prices available from (615) 576-8401.

Available to the public from the National Technical Information Service, U.S. Department of Commerce, 5285 Port Royal Road, Springfield, VA 22161. 


\section{DISCLAIMER}

Portions of this document may be illegible in electronic image products. Images are produced from the best available original document. 
Consequence Analyses Following Potential Savannah River

WSRC-TR-99-00108

Site Hydrological Releases (U)

Project: Emergency Preparedness Issues for Waterborne Releases

Document: WSRC-TR-99-00108

Title: Consequence Analyses Following Potential Savannah River Site Hydrological Releases (U)

WSMS Approvals:
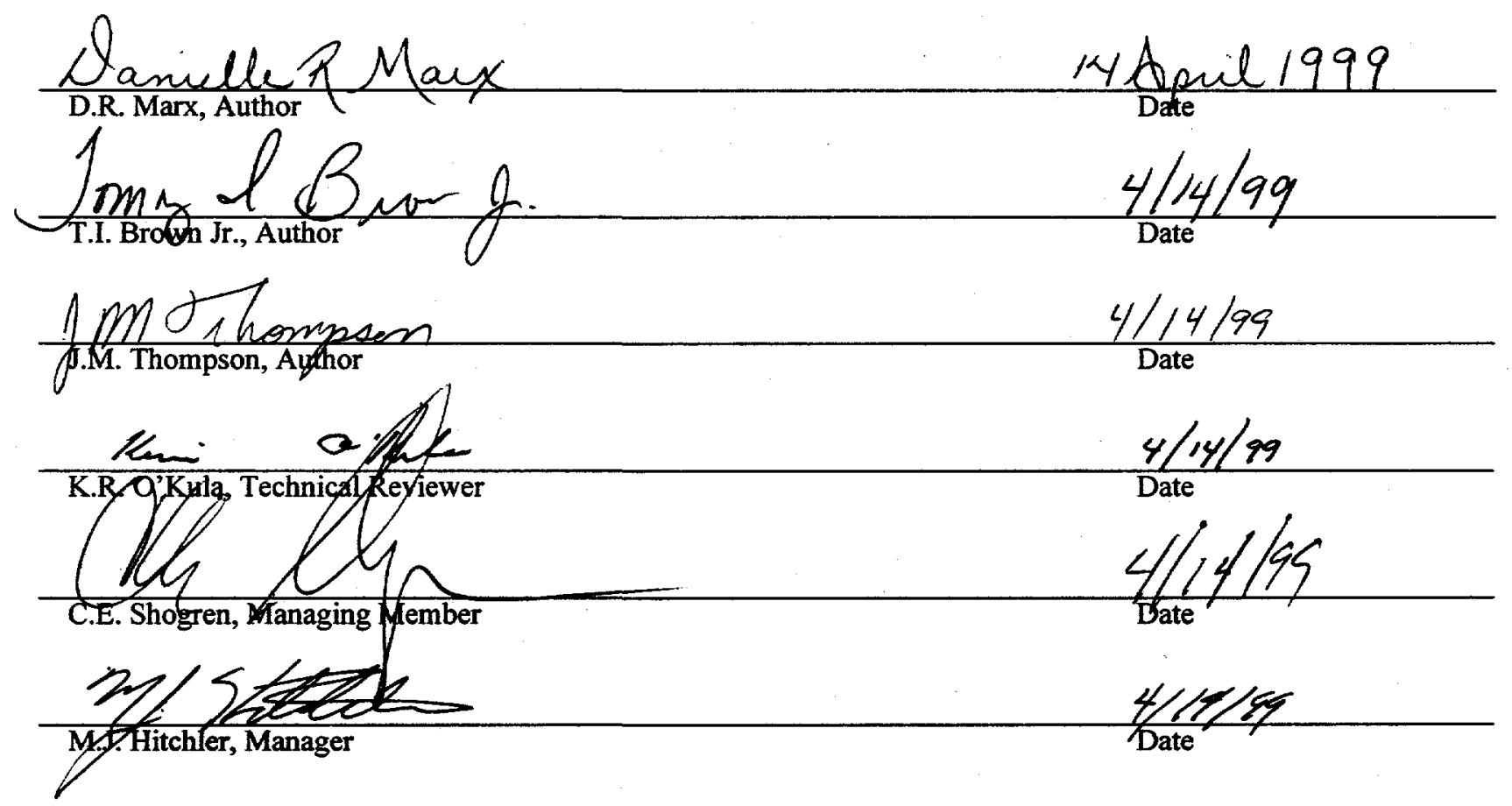
Consequence Analyses Following Potential Savannah River

WSRC-TR-99-00108

Site Hydrological Releases (U)

This Page Intentionally Left Blank 


\section{EXECUTIVE SUMMARY}

Postulated accidental releases of radiological material to surface water bodies on the Savannah River Site (SRS) and the resulting downstream contamination of the Savannah River pose a potential threat to downstream river users. To analyze this potential threat, SRS selected the hydrological code STREAM2 to model the downstream flow of radionuclides (Brown and Marx 1999). Hydrological release scenarios from three SRS areas were selected to examine the potential consequence to downstream populations. Calculated concentrations for all three releases at the City of Savannah water treatment plant intake indicate that radionuclide concentrations will surpass regulatory guidance for the entire passage time (ranging from 40-60 hours post release to $175-300$ hours post release, depending upon flow conditions and release location). During this time, it is recommended that offsite officials should halt water intake from the Savannah River. 
This Page Intentionally Left Blank 


\section{Table of Contents}

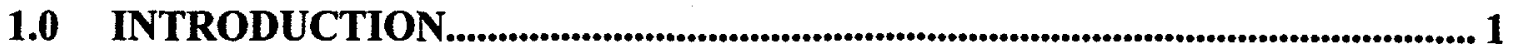

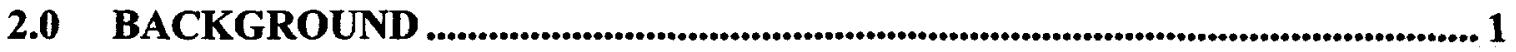

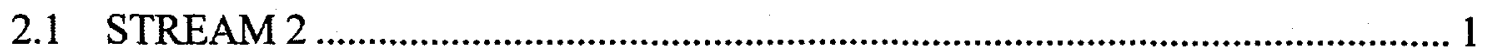

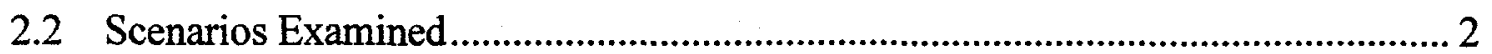

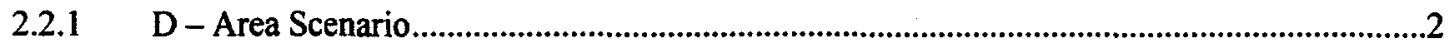

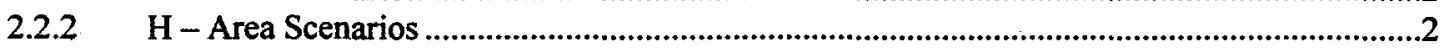

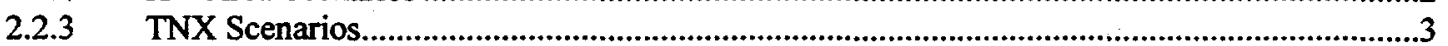

3.0 EVALUATION CRITERIA AND REGULATORY GUIDANCE .................... 3

3.1 FDA Derived Intervention Levels ............................................................... 3

3.2 EPA Safe Drinking Water Standards .......................................................... 5

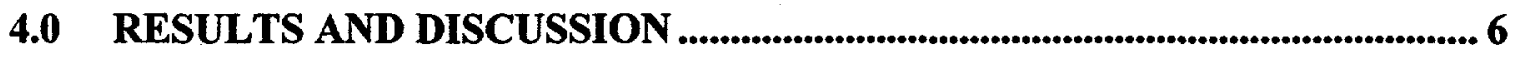

4.1 Downstream Concentrations and Time-to-impact Values..................................... 6

4.2 Comparison with Regulatory Guidance ............................................................... 7

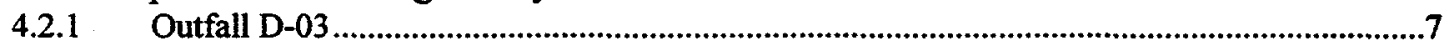

4.2.2 Outfall X-08

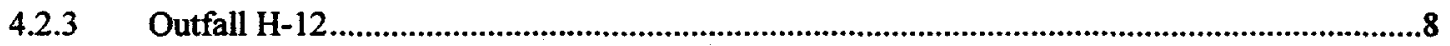

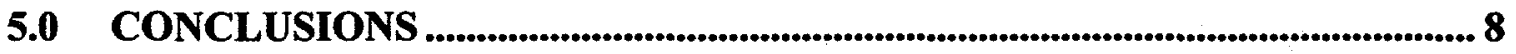

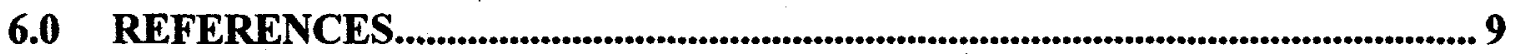

APPENDIX A ANNUAL CONCENTRATIONS RESULTING IN EPA

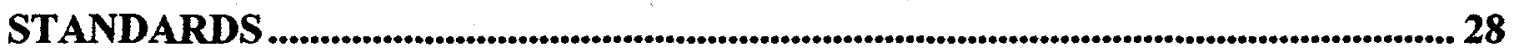

APPENDIX B RADIONUCLIDE CONCENTRATIONS FOR OUTFALL H-12.. 29

APPENDIX C RATIOS OF RADIONUCLIDE CONCENTRATION TO TOTAL CONCENTRATION FOR H-AREA RELEASES ............................................... 34 


\section{List of Tables}

Table 1 Radionuclide Inventory for the H-Canyon Coil and Tube Failure Event.............2

Table 2 Source Term for H-Area Tank Farm Leak and Spill Event........................3

Table 3 Flow Rates for the Savannah River and SRS Tributaries........................... 3

Table 4 DILs for Radionuclide Groups and other Radionuclides..........................5

Table 5 Maximum Contamination Levels for Specific Radionuclides.....................5

Table 6 Outfall D-03 Calculated Peak Concentrations and the Time-to-Impact Values for a $2.58 \mathrm{E}+06 \mathrm{Ci}$ Release ${ }^{3} \mathrm{H}$

Table 7 Outfall X-08 Calculated Peak Concentrations and the Time-to-Impact Values.....6

Table 8 Outfall H-12 Calculated Peak Concentrations and the Time-to-Impact Values for H-Canyon Coil and Tube Failure.

Table 9 Outfall H-12 Calculated Peak Concentrations and the Time-to-Impact Values for Tank Farm Leak and Spill Event.

\section{List of Figures}

Figure 1 Calculated Tritium Concentration, D-Area Release, Minimum Flow.............. 12

Figure 2 Calculated Tritium Concentration, D-Area Release, Median Flow................. 13

Figure 3 Calculated Tritium Concentration, D-Area Release, Mean Flow................. 14

Figure 4 Calculated Tritium Concentration, D-Area Release, Maximum Flow..............15

Figure 5 Calculated Concentration, TNX Release, Minimum Flow...................... 16

Figure 6 Calculated Concentration, TNX Release, Median Flow......................... 17

Figure 7 Calculated Concentration, TNX Release, Mean Flow............................. 18

Figure 8 Calculated Concentration, TNX Release, Maximum Flow........................19

Figure 9 Calculated Concentration, H-Canyon Release, Minimum Flow..................20

Figure 10 Calculated Concentration, H-Canyon Release, Median Flow....................21

Figure 11 Calculated Concentration, H-Canyon Release, Mean Flow......................22

Figure 12 Calculated Concentration, H-Canyon Release, Maximum Flow................ 23

Figure 13 Calculated Concentration, H-Tank Farm Release, Minimum Flow..............24

Figure 14 Calculated Concentration, H-Tank Farm Release, Median Flow................25

Figure 15 Calculated Concentration, H-Tank Farm Release, Mean Flow..................26

Figure 16 Calculated Concentration, H-Tank Farm Release, Maximum Flow............. 27 


\subsection{INTRODUCTION}

Postulated accidental releases of radiological material to surface water bodies on the Savannah River Site (SRS) and the resulting downstream contamination of the Savannah River pose a potential threat to downstream river users. To analyze this potential threat, SRS selected the hydrological code STREAM2 to model the downstream flow of radionuclides (Brown and Marx 1999). Hydrological release scenarios from three SRS areas were selected to examine the potential consequence to downstream populations.

\subsection{BACKGROUND}

The Savannah River Technology Center (SRTC) hydrological modeling code STREAM2 and the scenarios determined for examination of potential downstream consequences are described below.

\section{$2.1 \quad$ STREAM 2}

STREAM2 is the SRS Weather Information and Display System (WINDS) emergency response hydrological modeling code (Chen 1995, Chen 1996a, Chen 1996b). It is designed to model the transport of pollutants from a release point within SRS to various points downstream on the Savannah River. To correct the problems of its predecessor, STREAM, with spurious oscillations in the concentration profile for long duration releases, STREAM2 incorporates the U.S. Environmental Protection Agency (EPA) WASP5 code to replace the STREAM transport and diffusion module (Chen 1998a). The WASP5 code is a water quality analysis program that simulates one-dimensional pollutant transport and fate through surface water. Additional input files describing the geometry of the pollutant pathway from the release point to the coastal area and the stream/river flow conditions are used in STREAM2 for simulations (Chen 1998b).

STREAM2 is composed of three modules: the calculation, pre-processor, and post-processor modules. The pre-processor module user interface consists of the time, date, type, location, calculation units, amount, and duration of the release. The input data from the user is transferred from the pre-processor to the calculation module, which calculates the pollutant concentrations and transport time at downstream locations. The post-processor module displays the output data from the pollutant concentrations and transport times on the computer screen in graphical and tabular form.

Three important assumptions are used in STREAM2 modeling (Chen 1999). First, the downstream Savannah River flow rate is assumed to be constant. Second, it is assumed that radionuclide loss does not occur during transport from the release point to the downstream location of interest. Third, it is assumed that cross sectional uniform mixing occurs.

STREAM2 is conservative in its modeling approach and does not include physical factors that would reduce calculated downstream concentration. Two parameters currently under consideration for potential inclusion in STREAM2 are dilution and deposition. Preliminary examination has indicated that incorporating dilution into the model is unnecessary since the additional dilution provided by other sources is relatively insignificant (i.e., 10\%). However, 
incorporation of deposition changes may be of benefit and should be examined further. Modeling deposition in STREAM2 may reduce the downstream radionuclide concentration by as much as a factor of 2 for certain radionuclides, such as cesium and plutonium, based on information in the Radiological Assessment Program (RAP) reports (Carlton 1992a, 1992b). Incorporations of either of these two physical factors, if deemed appropriate for STREAM2, will occur at a later date.

\subsection{Scenarios Examined}

Three SRS aqueous outfalls - D-03, H-12, X-08 - were examined. These outfalls were agreed upon jointly by Westinghouse Savannah River Company (WSRC), the Department of Energy (DOE), and the States of Georgia and South Carolina, and are documented in WSRC-TR-980411, Rev. 1 (Brown 1999). Descriptions of the scenarios selected for modeling are described in WSRC-TR-98-00448, Rev. 2 (Brown and Marx 1999). Brief descriptions of the selected scenarios are given below.

\subsubsection{D - Area Scenario}

In the D - Area Heavy Water processing and drum storage facilities, tritium is the only radioactive material that has the potential to represent any threat of significance to the environment, general public, and onsite personnel. Buildings in the Heavy Water Facility are not seismically qualified or hardened to withstand the forces of high winds or tornadoes. Therefore, it is assumed that the buildings fail and result in a maximum release of tritium during the range of natural phenomena hazard (NPH) events. As such, only one accident event will be evaluated for D-Area. The aqueous release source term resulting from high winds, tornadoes, or earthquakes is $2.58 \times 10^{+6}$ curies of tritium and is assumed to be instantaneous.

\subsection{2 $\mathrm{H}$ - Area Scenarios}

Two operational accidents have been selected for modeling H-Area accidents. In the H-Canyon Coil and Tube Failure liquid pathway, the entire inventory of radioactivity assumed contained in one coil is released to Four Mile Creek. The release is assumed to be instantaneous. The radionuclide inventory resulting in the maximum release is shown in Table 1 (WSRC 1998a).

Table 1 Radionuclide Inventory for the H-Canyon Coil and Tube Failure Event

\begin{tabular}{|l|l|l|l|l|l|l|l|}
\hline Isotope & Curies & Isotope & Curies & Isotope & Curies & Isotope & Curies \\
\hline Sr-89 & $1.4 \mathrm{E}+4$ & $\mathrm{Ag}-110$ & $7.1 \mathrm{E}+1$ & Pr-144 & $3.8 \mathrm{E}+4$ & Pa-233 & $0.0 \mathrm{E}+0$ \\
\hline Sr-90 & $6.8 \mathrm{E}+2$ & Sn-123 & $6.8 \mathrm{E}+1$ & Pm-147 & $3.8 \mathrm{E}+3$ & Pu-238 & $1.0 \mathrm{E}+2$ \\
\hline Y-90 & $2.5 \mathrm{E}+2$ & Sb-125 & $7.8 \mathrm{E}+1$ & Pm-148m & $1.0 \mathrm{E}+2$ & Pu-239 & $4.6 \mathrm{E}-1$ \\
\hline Y-91 & $2.1 \mathrm{E}+4$ & $\mathrm{Te}-127$ & $1.2 \mathrm{E}+2$ & $\mathrm{Eu}-155$ & $4.2 \mathrm{E}+1$ & Pu-240 & $4.6 \mathrm{E}-1$ \\
\hline Zr-95 & $2.7 \mathrm{E}+4$ & $\mathrm{Te}-129$ & $1.1 \mathrm{E}+2$ & $\mathrm{U}-234$ & $1.2 \mathrm{E}-1$ & Pu-241 & $1.3 \mathrm{E}+2$ \\
\hline Nb-95 & $5.0 \mathrm{E}+4$ & $\mathrm{Cs}-134$ & $1.7 \mathrm{E}+3$ & $\mathrm{U}-235$ & $1.0 \mathrm{E}-3$ & Pu-242 & $1.5 \mathrm{E}-3$ \\
\hline Ru-103 & $5.1 \mathrm{E}+3$ & $\mathrm{Cs}-137$ & $2.0 \mathrm{E}+3$ & $\mathrm{U}-236$ & $3.2 \mathrm{E}-2$ & Am-241 & $2.7 \mathrm{E}+0$ \\
\hline Ru-106 & $2.6 \mathrm{E}+3$ & $\mathrm{Ce}-141$ & $5.3 \mathrm{E}+3$ & $\mathrm{U}-238$ & $8.7 \mathrm{E}-5$ & & \\
\hline Rh-106 & $2.6 \mathrm{E}+3$ & $\mathrm{Ce}-144$ & $3.8 \mathrm{E}+4$ & Np-237 & $2.2 \mathrm{E}-2$ & & \\
\hline
\end{tabular}

In the H-Tank Farm liquid leak and spill event, 1,000 gallons of Slurry Sludge is released. The release is subject to runoff or is soaked into the surrounding soil. The total isotopic source term 
for the Tank Farm leak and spill event is listed in Table 2 (WSRC 1998b). The release is assumed to be instantaneous.

Table 2 Source Term for H-Area Tank Farm Leak and Spill Event

\begin{tabular}{|l|l|l|l|}
\hline Isotope & Curies & Isotope & Curies \\
\hline Sr-90 & $1.2 \mathrm{E}+5$ & Pu-238 & $4.2 \mathrm{E}+4$ \\
\hline Ru-106 & $1.6 \mathrm{E}+2$ & Pu-239 & $3.5 \mathrm{E}+1$ \\
\hline Cs-134 & $6.5 \mathrm{E}+2$ & Pu-240 & $2.6 \mathrm{E}+1$ \\
\hline Cs-137 & $4.5 \mathrm{E}+3$ & $\mathrm{Pu}-241$ & $4.7 \mathrm{E}+3$ \\
\hline Ce-144 & $4.4 \mathrm{E}+3$ & $\mathrm{Am}-241$ & $4.1 \mathrm{E}+1$ \\
\hline
\end{tabular}

\subsubsection{TNX Scenarios}

The only large amounts of radioactive materials at TNX are solutions of uranyl nitrate stored in two tanks in the vicinity of 677-T. The total quantity of depleted uranium is $1569 \mathrm{~kg}$. The Hazard Assessment Document (HAD) analyzed the solution as natural uranium $(99.27 \%$ U-238, $0.72 \% \mathrm{U}-235$, and $\left.5.5 \times 10^{-3} \% \mathrm{U}-234\right)$. The total curie content of the two tanks is $1.08 \mathrm{Ci}(0.52$ Ci U-238, 0.02 Ci U-235, 0.54 Ci U-234).

\subsection{Evaluation CRITERia ANd Regulatory Guidance}

The output for the modeled scenarios will be examined for several parameters. Each scenario will be modeled using mean, minimum, maximum, and median flow rates for the Savannah River and tributaries passing through SRS. Flow rates for the Savannah River and two tributaries are shown in Table 3. Time-to-impact values for two downstream locations intersection of the Savannah River and Highway 301 and at the City of Savannah water treatment plant intake - will be examined. This will aid in determining the time urgency of an aqueous release. Peak and time-integrated radionuclide concentrations will be calculated for three locations: the entrance of the site stream to the Savannah River, the Savannah River and Highway 301 intersection, and the City of Savannah water treatment plant intake. These concentrations will be compared with regulatory limits (FDA 1998, EPA 1998).

Table 3 Flow Rates for the Savannah River and SRS Tributaries

\begin{tabular}{|l|c|c|c|c|}
\hline \multirow{2}{*}{ Water Body } & \multicolumn{4}{|c|}{ Flow Rates (cfs) } \\
\cline { 2 - 5 } & Minimum & Median & Mean & Maximum \\
\hline Savannah River & 2810.0 & 7030.0 & 9384.4 & 64400.0 \\
\hline Beaver Dam Creek & 27.0 & 83.0 & 81.0 & 30.0 \\
\hline Four Mile Branch & 6.7 & 30.0 & 41.9 & 1200.0 \\
\hline
\end{tabular}

\subsection{FDA Derived Intervention Levels}

The Food and Drug Administration (FDA) Derived Intervention Levels (DILs) are limits on the concentrations permitted in human food distributed in commerce to prevent consumption of undesirable amounts of radionuclides and apply in the first year after an accident (FDA 1998). The DIL corresponds to the concentration in food present throughout the relevant period of time that, in the absence of any intervention, could lead to an individual receiving a radiation dose equal to the Protective Action Guide (PAG). The PAGs for the ingestion pathway are 0.5 rem committed effective dose equivalent or 5 rem committed dose equivalent to an individual tissue 
or organ, whichever is most limiting. The DILs are based on the entire diet and include tap water used for drinking.

FDA (1998) places selected radionuclides into five primary groups, each with common characteristics. These groups are:

- $\operatorname{Sr}-90$

- I-131

- $\mathrm{Cs}-134+\mathrm{Cs}-137$
- $\mathrm{Pu}-238+\mathrm{Pu}-239+\mathrm{Am}-241$

- $\mathrm{Ru}-103+\mathrm{Ru}-106$

The DIL for each radionuclide group is applied independently (i.e., there is no additivity between groups). If multiple radionuclides are present in a group, the DIL applies to the sum of the concentrations of those radionuclides, except for the $\mathrm{Ru}-103+\mathrm{Ru}-106$ group. These groups were developed to aid analyses at a variety of nuclear facilities. Nuclear waste storage facilities and nuclear fuel reprocessing facilities are expected to have $\mathrm{Sr}-90, \mathrm{Cs}-137, \mathrm{Pu}-239$, and $\mathrm{Pu}-238$ as major contributors.

FDA recommends that DILs from the five groups be applied immediately following an accident. Early evaluation of other radionuclides that may have been released is not required. However, an evaluation should be performed as soon as possible to ensure the DILs are appropriate; presumably, this would include evaluating DILs for the five groups as well as those for radionuclides not in the groups.

The five radionuclide groups are not sufficient to cover accidents at all types of facilities or locations. FDA (1998) notes the example of transportation accidents that may release radionuclides not in the radionuclide groups. Although such releases are not specifically addressed (in the five groups), FDA recommends that an evaluation of the radiation dose from ingestion of these other radionuclides be performed to determine if protective action guides will be exceeded. Appendix E of FDA (1998) presents DILs for 15 additional radionuclides.

Some source terms at SRS are postulated to be dominated by tritiated water. DILs for tritium in water and organically bound forms were derived using methodology consistent with FDA (1998) (Tharakan 1999). DILs for the five radionuclide groups and other radionuclides present in the scenarios described above are listed in Table 4. 
Table 4 DILs for Radionuclide Groups and other Radionuclides (most limiting of all diets)

\begin{tabular}{|l|c|l|c|}
\hline \multicolumn{1}{|c|}{$\begin{array}{c}\text { Radionuclide } \\
\text { Group }\end{array}$} & DIL (pCi/L) & $\begin{array}{c}\text { Radionuclide } / \\
\text { Group }\end{array}$ & DIL (pCi/L) \\
\hline Sr-90 & $4.3 \mathrm{E}+03$ & Te-132 & $1.2 \mathrm{E}+05$ \\
\hline $\mathrm{I}-131$ & $4.6 \mathrm{E}+03$ & $\mathrm{I}-129$ & $1.5 \mathrm{E}+03$ \\
\hline $\mathrm{Cs}-134+\mathrm{Cs}-137$ & $3.2 \mathrm{E}+04$ & $\mathrm{I}-133$ & $1.9 \mathrm{E}+05$ \\
\hline $\begin{array}{l}\text { Pu-238+ Pu-239 } \\
+\mathrm{Am}-241\end{array}$ & & $\mathrm{Ba}-140$ & $1.9 \mathrm{E}+05$ \\
\cline { 3 - 4 } & $5.4 \mathrm{E}+01$ & $\mathrm{Ce}-141$ & $1.9 \mathrm{E}+05$ \\
\hline Ru-103* & $1.8 \mathrm{E}+05$ & $\mathrm{Ce}-144$ & $1.4 \mathrm{E}+04$ \\
\hline Ru-106* & $1.2 \mathrm{E}+04$ & $\mathrm{~Np}-237$ & $1.1 \mathrm{E}+02$ \\
\hline Sr-89 & $3.8 \mathrm{E}+04$ & $\mathrm{~Np}-239$ & $7.6 \mathrm{E}+05$ \\
\hline $\mathrm{Y}-91$ & $3.2 \mathrm{E}+04$ & $\mathrm{Pu}-241$ & $3.2 \mathrm{E}+03$ \\
\hline $\mathrm{Zr}-95$ & $1.1 \mathrm{E}+05$ & $\mathrm{Cm}-242$ & $5.1 \mathrm{E}+03$ \\
\hline Nb-95 & $3.2 \mathrm{E}+05$ & $\mathrm{Cm}-244$ & $5.4 \mathrm{E}+01$ \\
\hline HTO & $5.9 \mathrm{E}+06$ & $\mathrm{OBT}$ & $2.4 \mathrm{E}+06$ \\
\hline
\end{tabular}

* Due to the large differences in DILs for Ru-103 and $\mathrm{Ru}-106$, the individual concentrations of Ru-103 and Ru-106 are divided by their respective DILs and then summed. The sum must be less than one.

\subsection{EPA Safe Drinking Water Standards}

For radionuclides present in consumable water, Environmental Protection Agency (EPA) guidance indicates that the sum of their annual dose equivalent to the total body or to any organ shall not exceed $4 \mathrm{mrem} / \mathrm{year}$. The concentration of man-made radionuclides causing a $4 \mathrm{mrem}$ total body or organ dose equivalent shall be calculated on the basis of a 2 liter per day drinking water intake. This is based on the 168 hour data listed in "Maximum Permissible Body Burdens and Maximum Permissible Concentration of Radionuclides in Air or Water for Occupational Exposure," NBS Handbook 69 as amended August 1963, U.S. Department of Commerce. Maximum radionuclide concentrations in the community water systems that result in an annual dose of 4 mrem are listed in the spreadsheets in Appendix A.

In addition to the $4 \mathrm{mrem} / \mathrm{year}$ maximum contamination levels for beta particle and photon radioactivity from man-made radionuclides in community water systems, certain radionuclides have specific concentration limits. These radionuclides are listed in Table 5.

Table 5 Maximum contamination levels for specific radionuclides

\begin{tabular}{|c|c|c|}
\hline Radionuclide & Critical Organ & $\begin{array}{c}\text { Maximum Concentration } \\
(\mathrm{pCi} / \mathrm{L})\end{array}$ \\
\hline Tritium & Total body & 20,000 \\
\hline Strontium-90 & Bone marrow & 8 \\
\hline Combined radium-226 and radium-228 & 15 \\
\hline $\begin{array}{l}\text { Gross alpha particle activity (including radium-226 but excluding } \\
\text { radon and uranium)[41 FR 28404, July 9, 1976] }\end{array}$ & \\
\hline
\end{tabular}

EPA Safe Drinking Water Standards are derived for chronic intakes over an entire year (i.e. contaminated water is consumed for an entire year). Public exposure following any of the scenarios listed above would be acute and result from water consumed during the time in which the contaminated water flowed passed the intake point. Thus, while the EPA standards are 
applicable as a reference, the FDA DILs are more appropriate for the acute releases examined in this report.

\subsection{Results AND Discussion}

Calculated STREAM2 results for the scenarios described in Section 2.2 are reported in Chen (1999). The downstream river concentrations and the time following release at which the peak concentration reaches the downstream receptor are quantitatively discussed in Section 4.1. The length of time following a release for which regulatory limits are exceeded at a downstream receptor is qualitatively examined in Section 4.2

\subsection{Downstream Concentrations and Time-to-Impact Values}

Calculated downstream concentrations for Outfall D-03 are presented in Table 6 (Chen 1999). For all four flow conditions, the peak tritium concentration and its time-of-arrival at the Savannah River entrance, Highway 301, and the City of Savannah water treatment plant are listed. The time-integrated concentrations are also listed. For the City of Savannah water treatment plant, the primary point of concern, Table 6 indicates the peak concentration arrives 2 to 5 days following the release, depending upon flow conditions. Entrance into the Savannah River occurs approximately 4 hours following the release. From examining Table 6 , it is evident that as the Savannah River flow rate increases, the peak tritium concentration and the contaminant travel time decrease. This is consistent for all outfalls.

Table 6 Outfall D-03 Calculated Peak Concentrations and the Time-to-Impact Values for a 2.58E +06 Ci Release ${ }^{3} \mathrm{H}$

\begin{tabular}{|c|c|c|c|c|c|c|c|}
\hline & \multicolumn{6}{|c|}{ Calculated Peak Concentration and Time-to-impact Values } & \multirow{3}{*}{$\begin{array}{l}\text { Time-Integrated } \\
\text { Concentration } \\
\text { (pCi / L) Hour }\end{array}$} \\
\hline \multirow{2}{*}{$\begin{array}{l}\text { Flow } \\
\text { Condition }\end{array}$} & \multicolumn{2}{|c|}{ Savannah River } & \multicolumn{2}{|c|}{ Highway 301} & \multicolumn{2}{|c|}{ Savannah Water Plant } & \\
\hline & $\mathrm{pCi} / \mathrm{L}$ & Hours & $\mathrm{pCi} / \mathrm{L}$ & Hours & $\mathrm{pCi} / \mathrm{L}$ & Hours & \\
\hline Minimum & $1.99 \mathrm{E}+09$ & 6 & $1.06 \mathrm{E}+09$ & 35 & $6.27 \mathrm{E}+08$ & 113 & $8.92 \mathrm{E}+09$ \\
\hline Median & $1.27 \mathrm{E}+09$ & 4 & $6.35 \mathrm{E}+08$ & 26 & $3.69 \bar{E}+08$ & 86 & $3.56 \mathrm{E}+09$ \\
\hline Mean & $9.30 \mathrm{E}+08$ & 4 & $5.08 \mathrm{E}+08$ & 25 & $3.02 \mathrm{E}+08$ & 79 & $2.67 \mathrm{E}+09$ \\
\hline Maximum & $1.48 \mathrm{E}+08$ & 4 & $1.05 \mathrm{E}+08$ & 16 & $6.29 \mathrm{E}+07$ & 49 & $3.92 \mathrm{E}+08$ \\
\hline
\end{tabular}

Calculated downstream concentrations for Outfall X-08 are shown in Table 7. The concentrations listed are the total for all radionuclides released (1.08 $\mathrm{Ci}$ uranium). For the City of Savannah water treatment plant, the time delay between release and arrival of peak concentration ranges from approximately 2 to 5 days, depending upon flow conditions. Due to the close proximity of the X-08 outfall to the Savannah River, the radionuclide concentrations at entrance to the river are not reported.

Table 7 Outfall X-08 Calculated Peak Concentrations and the Time-to-Impact Values

\begin{tabular}{|l|c|c|c|c|l|}
\hline \multirow{2}{*}{$\begin{array}{l}\text { Flow } \\
\text { Condition }\end{array}$} & \multicolumn{2}{|c|}{ Calculated Peak Concentration and Time-to-impact Values } & \multirow{2}{*}{$\begin{array}{l}\text { Time-Integrated } \\
\text { Concentration }\end{array}$} \\
\cline { 2 - 5 } & $\mathrm{pCi} / \mathrm{L}$ & Hours & $\mathrm{pCi} / \mathrm{L}$ & Hours & (pCi / L) Hour \\
\hline Minimum & $5.12 \mathrm{E}+02$ & 32 & $2.75 \mathrm{E}+02$ & 109 & $3.74 \mathrm{E}+03$ \\
\hline Median & $4.63 \mathrm{E}+02$ & 24 & $2.48 \mathrm{E}+02$ & 83 & $1.49 \mathrm{E}+03$ \\
\hline Mean & $4.22 \mathrm{E}+02$ & 22 & $2.26 \mathrm{E}+02$ & 77 & $1.12 \mathrm{E}+03$ \\
\hline Maximum & $6.09 \mathrm{E}+01$ & 14 & $3.29 \mathrm{E}+01$ & 46 & $1.64 \mathrm{E}+02$ \\
\hline
\end{tabular}


Calculated downstream concentrations for Outfall H-12 are shown in Tables 8 and 9 for the HCanyon Coil and Tube Failure and the Tank Farm leak and spill, respectively. The concentrations listed are the total for all radionuclides released (Appendix B lists concentrations for each radionuclide independently) (Chen 1999). For the City of Savannah water treatment plant, the time delay between release and arrival of peak concentration ranges from approximately 3 to 9 days, depending upon flow conditions. The hold up time on SRS is 1.5 to 4.5 days, depending upon flow conditions.

Table 8 Outfall H-12 Calculated Peak Concentrations and the Time-to-Impact Values for H-Canyon Coil and Tube Failure Calculated Peak Concentration and Time-to-impact Values

\begin{tabular}{|c|c|c|c|c|c|c|c|}
\hline \multirow{3}{*}{$\begin{array}{l}\text { Flow } \\
\text { Condition }\end{array}$} & \multicolumn{6}{|c|}{ Calculated Peak Concentration and Time-to-impact Values } & \multirow{3}{*}{$\begin{array}{l}\text { Time-Integrated } \\
\text { Concentration } \\
\text { (pCi / L) Hour }\end{array}$} \\
\hline & \multicolumn{2}{|c|}{ Savannah River } & \multicolumn{2}{|c|}{ Highway 301} & \multicolumn{2}{|c|}{ Savannah Water Plant } & \\
\hline & $\mathrm{pCi} / \mathrm{L}$ & Hours & $\mathrm{pCi} / \mathrm{L}$ & Hours & $\mathrm{pCi} / \mathrm{L}$ & Hours & \\
\hline Minimum & $2.60 \mathrm{E}+07$ & 112 & $2.52 \mathrm{E}+07$ & 141 & $2.34 \mathrm{E}+07$ & 219 & $7.37 \mathrm{E}+08$ \\
\hline Median & $1.68 \mathrm{E}+07$ & 75 & $1.63 \mathrm{E}+07$ & 97 & $1.51 \mathrm{E}+07$ & 157 & $2.94 E+08$ \\
\hline Mean & $1.37 \mathrm{E}+07$ & 69 & $1.33 \mathrm{E}+07$ & 90 & $1.23 \mathrm{E}+07$ & 144 & $2.20 \mathrm{E}+08$ \\
\hline Maximum & $3.22 \mathrm{E}+06$ & 35 & $3.12 \mathrm{E}+06$ & 47 & $2.89 \mathrm{E}+06$ & 79 & $3.16 E+07$ \\
\hline
\end{tabular}

Table 9 Outfall H-12 Calculated Peak Concentrations and the Time-to-Impact Values for Tank Farm Leak and Spill Event

\begin{tabular}{|c|c|c|c|c|c|c|c|}
\hline & \multicolumn{6}{|c|}{ Calculated Peak Concentration and Time-to-impact Values } & \multirow{2}{*}{$\begin{array}{l}\text { Time-Integrated } \\
\text { Concentration }\end{array}$} \\
\hline \multirow{2}{*}{$\begin{array}{l}\text { Flow } \\
\text { Condition }\end{array}$} & \multicolumn{2}{|c|}{ Savannah River } & \multicolumn{2}{|c|}{ Highway 301} & \multicolumn{2}{|c|}{ Savannah Water Plant } & \\
\hline & $\mathrm{pCi} / \mathrm{L}$ & Hours & $\mathrm{pCi} / \mathrm{L}$ & Hours & $\mathrm{pCi} / \mathrm{L}$ & Hours & (pCi/L) Hour \\
\hline Minimum & $2.19 \mathrm{E}+07$ & 112 & $2.10 \mathrm{E}+07$ & 141 & $1.96 \mathrm{E}+07$ & 220 & $6.15 \mathrm{E}+08$ \\
\hline Median & $1.41 \mathrm{E}+07$ & $\overline{75}$ & $1.36 \mathrm{E}+07$ & 97 & $1.26 \mathrm{E}+07$ & 157 & $2.45 \mathrm{E}+08$ \\
\hline Mean & $1.14 \mathrm{E}+07$ & 69 & $1.11 \mathrm{E}+07$ & 89 & $1.03 \mathrm{E}+07$ & $\overline{144}$ & $1.84 \mathrm{E}+08$ \\
\hline Maximum & $2.69 \mathrm{E}+06$ & $\overline{35}$ & $2.61 E+06$ & 47 & $2.42 \mathrm{E}+06$ & 79 & $2.64 E+07$ \\
\hline
\end{tabular}

\subsection{Comparison with Regulatory Guidance}

Graphical presentations of the concentration changes with respect to time for the downstream locations are shown in Figures 1-16 (taken from Chen 1999). Discussion of these, in relation to regulatory guidance's are presented below.

\subsubsection{Outfall D-03}

The D-Area Heavy Water and Drum Storage Facility aqueous release exceeds the HTO DIL of $5.94 \times 10^{+6} \mathrm{pCi} / \mathrm{L}$ and the EPA maximum concentration of $20,000 \mathrm{pCi} / \mathrm{L}$ at all downstream locations. From Figures 1-4 it is evident that the radionuclide concentration in the river exceeds the DIL for the entire passage of the contaminant near the City of Savannah water treatment plant intake. Thus, it is recommended that water used for drinking should not be removed from the Savannah River during this time. Under minimum flow conditions, Figure 1 indicates that removal of drinking water from the Savannah River should cease approximately 90 hours following the release and may resume approximately 130 hours following the release. For maximum flow conditions, Figure 4 indicates that water removal must halt from 40 to 60 hours following the release. 


\subsubsection{Outfall X-08}

For the radionuclides present in the TNX source term, FDA DILs are not provided. However, the maximum concentrations calculated in Appendix A based on the EPA dosage of $4 \mathrm{mrem} / \mathrm{year}$ may be used. Figures 5-8 indicate that the radionuclide concentration in the river exceeds the EPA standards for the entire passage of the contaminant near the City of Savannah water treatment plant intake. However, EPA concentrations are based on chronic intakes. Limits comparable to FDA DILs should be calculated were a similar release to occur. For minimum flow rates, Figure 5 indicates that water removal should cease at 85 hours following the release and may resume at 135 hours following the release. Figure 8 shows that for maximum flow rates, this time is from $35-55$ hours post release.

\subsubsection{Outfall $\mathrm{H}-12$}

Figures 9-12 and 13-16 graph the change in total concentration for the H-Canyon Coil and Tube Failure and the H-Tank Farm leak and spill events at the downstream locations, respectively. Concentrations for each radionuclide can be calculated by examining the ratio of the radionuclide concentration (Appendix B) to the total concentration. This ratio stays constant throughout transport, regardless of flow conditions. Based on the percentage of total concentration for each radionuclide, DILs for each radionuclide in Table 4 can be calculated based on the total concentration (Appendix C).

For the H-Canyon Coil and Tube Failure, DILs are available for the following radionuclides:

- $\operatorname{Sr}-90$

- $\mathrm{Cs}-134+\mathrm{Cs}-137$

- $\mathrm{Pu}-238+\mathrm{Pu}-239+\mathrm{Am}-241$

- $\mathrm{Ru}-103+\mathrm{Ru}-106$
- $\mathrm{Sr}-89$

- Y-91

- $\mathrm{Ce}-141$

- $\mathrm{Ce}-144$
- $\mathrm{Np}-237$

- Zr-95

- $\mathrm{Nb}-95$

- Pu-241

Other radionuclides present in the source term will not be considered in this report. For the HTank Farm leak and spill, DILs are available for all radionuclides except Pu-241. The most limiting radionuclide group for both events is the Pu-238 + Pu-239 + Am-241 group. For all flow conditions, the DIL is surpassed the entire duration the radionuclide passes the City of Savannah water treatment plant intake. Additional radionuclides can be examined using Tables 9-12 for H-Canyon and 13-16 for Tank Farm and the recalculated DILs in Appendix C. Under minimum flow conditions, it is recommended that water intake should cease approximately 175 hours following the release and may resume at 300 hours post release. For maximum flow conditions, this reduces to a limit on withdrawal during the time period of $60-105$ hours post release.

\subsection{Conclusions}

Calculated concentrations for all three releases at the City of Savannah water treatment plant intake indicate that radionuclide concentrations will surpass regulatory guidance for the entire passage time. During these time periods, it is recommended that water used for drinking should not be removed from the Savannah River. Figures 1-16 provide qualitative time estimates for halting water intake from the Savannah River. Additionally, concentration ratios may be used to examine the concentrations of other radionuclides. 


\subsection{REFERENCES}

T.I Brown, Jr. (1999). Waterborne Release Monitoring and Surveillance Programs at the Savannah River Site, Westinghouse Savannah River Company, Aiken, SC, WSRC-TR-9800411, Rev 1 .

T.I. Brown, Jr., and D.R. Marx (1999). Selection of Hydrological Model for Waterborne Release $(U)$, Westinghouse Savannah River Company, Aiken, SC, WSRC-TR-98-00448, Rev. 2

W. Carlton et. al. (1992a). Assessment of Plutonium in the Savannah River Site Environment (U), Westinghouse Savannah River Company, Aiken, SC, WSRC-RP-92-879, Rev. 1.

W. Carlton et. al. (1992b). Cesium in the Savannah River Site Environment (U), Westinghouse Savannah River Company, Aiken, SC, WSRC-RP-92-250.

K-F Chen (1995). Revised STREAM Code and WASP5 Benchmark (U), Westinghouse Savannah River Company, Aiken, SC, WSRC-RP-95-598.

K-F Chen (1996a). Critical Contaminant/Critical Pathway Analysis-Surface Water Transport for Nonradioactive Contaminants (U), Westinghouse Savannah River Company, Aiken, SC, WSRC-RP-96-555.

K-F Chen (1996b). Revised STREAM Code Benchmarking with 1991. K-Reactor Tritiated Aqueous Release Incident ( $U$ ), Westinghouse Savannah River Company, Aiken, SC, WSRCRP-96-80.

K-F Chen (1998a). STREAM2 for SRS Aqueous Release Emergency Response (U), Westinghouse Savannah River Company, Aiken, SC, WSRC-TR-98-00234.

K-F Chen (1998b). Inter-Office Memorandum to D.R. Marx, "Hydrological Modeling for Waterborne Releases from D and H Areas (U)," Westinghouse Savannah River Company, Aiken, SC, SRT-NTS-980285 (16 November 1998).

K-F Chen (1999). Inter-Office Memorandum to D.R. Marx, "Hydrological Release Studies for Emergency Preparedness Issues (U)," Westinghouse Savannah River Company, Aiken, SC, SRT-NTS-xxxxx (30 March 1999).

C.D. Cope (1996). Beyond Design Basis Accident Analysis for a Seismic Event (U), Westinghouse Savannah River Company, Aiken, SC, S-CLC-G-00108.

DOE (1988). , Internal Dose Conversion Factors for Calculation of Dose to the Pubic. U.S. Department of Energy Office of Environmental Management, Washington, DC, DOE/EH0071.

DOE (1990). General Environmental Protection Program. U.S. Department Energy Order 5400.1, Washington, DC. 
DOE (1991). Environmental Regulatory Guide for Radiological Effluent Monitoring and Environmental Surveillance at U.S. Department of Energy Installations. U.S. Department of Energy, Washington, DC, DOE/EH-0173T.

DOE (1993). Radiation Protection of the Public and the Environment. U.S. Department of Energy Order 5400.5, Washington, DC.

DOE (1996). Natural Phenomena Hazards Design and Evaluation Criteria for Department of Energy Facilities. U.S. Department of Energy, Washington, DC, DOE-STD-1020-94, Change 1.

EPA (1998). National Primary Drinking Water Regulations. Environmental Protection Agency 40 CFR 141, Washington, DC.

FDA (1998). Accidental Contamination of Human Foods and Animal Feeds: Recommendations for States and Local Agencies. Food and Drug Administration, Rockville, MD.

D.M. Hamby (1991). LADTAP XL: An Improved Electronic Spreadsheet Version of LADTAP II, Westinghouse Savannah River Company, Aiken, SC, WSRC-RP-91-975.

E.P. Hope (1995). Consequence Analysis for Water Pathways for LRWHF SAR Accident Scenarios (U), Westinghouse Savannah River Company, Aiken, SC, S-CLC-G-00039, Rev. 0 .

E.P. Hope (1998). Inter-Office Memorandum to J.M. Thompson, "Transmittal of Surface Water Accidental Releases(U)," Westinghouse Safety Management Solutions, Inc., Aiken, SC, WSMS-M-SAE-98-00173 (5 November 1998).

NCRP (1976). Environmental Radiation and Measurements. National Council on Radiation Protection and Measurements Report No. 50, Bethesda, MD.

A.A. Simpkins (1998). Inter-Office Memorandum to D.R. Marx, "Aqueous Dose Modeling Using LADTAP XL and the Code's Applicability For Use with Emergency Response(U)," Westinghouse Savannah River Company, Aiken, SC, WSRC-SRT-EST-980436 (13 November 1998).

USNRC (1977a). Calculation of Annual Doses to Man from Routine Releases of Reactor Effluents for the Purpose of Evaluating Compliance with 10CFR Part 50 Appendix I. U.S. Nuclear Regulatory Commission Regulatory Guide 1.109, Washington, DC.

USNRC (1977b). Estimating Aquatic Dispersion of Effluents From Accidental and Routine Reactor Releases for The Purpose of Implementing Appendix 1. U.S. Nuclear Regulatory Commission Regulatory Guide 1.113, Washington, DC.

WSRC (1998a). H-Canyon Basis for Interim Operations, Westinghouse Savannah River Company, Aiken, SC, WSRC-RP-95-635, Rev. 4. 
WSRC (1998b). Liquid Radioactive Waste Handling Facility Safety Analysis Report, Westinghouse Savannah River Company, Aiken, SC, WSRC-SA-33. 
Figure 1 Calculated Tritium Concentration

\subsection{E+06 Ci Released from D-Area} Minimum Flow

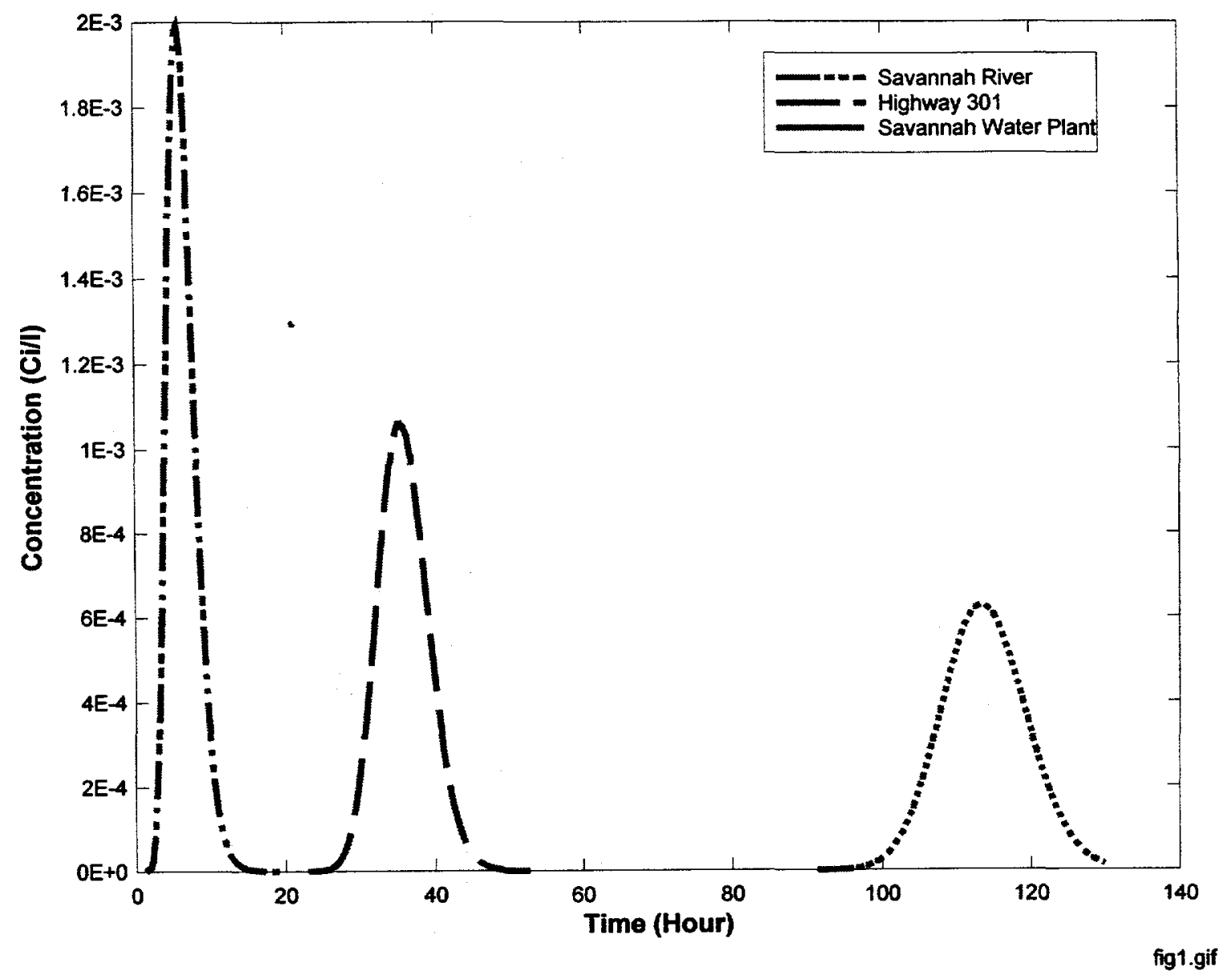


Figure 2 Calculated Tritium Concentration

2.58E+06 Ci Released from D-Area Median Flow

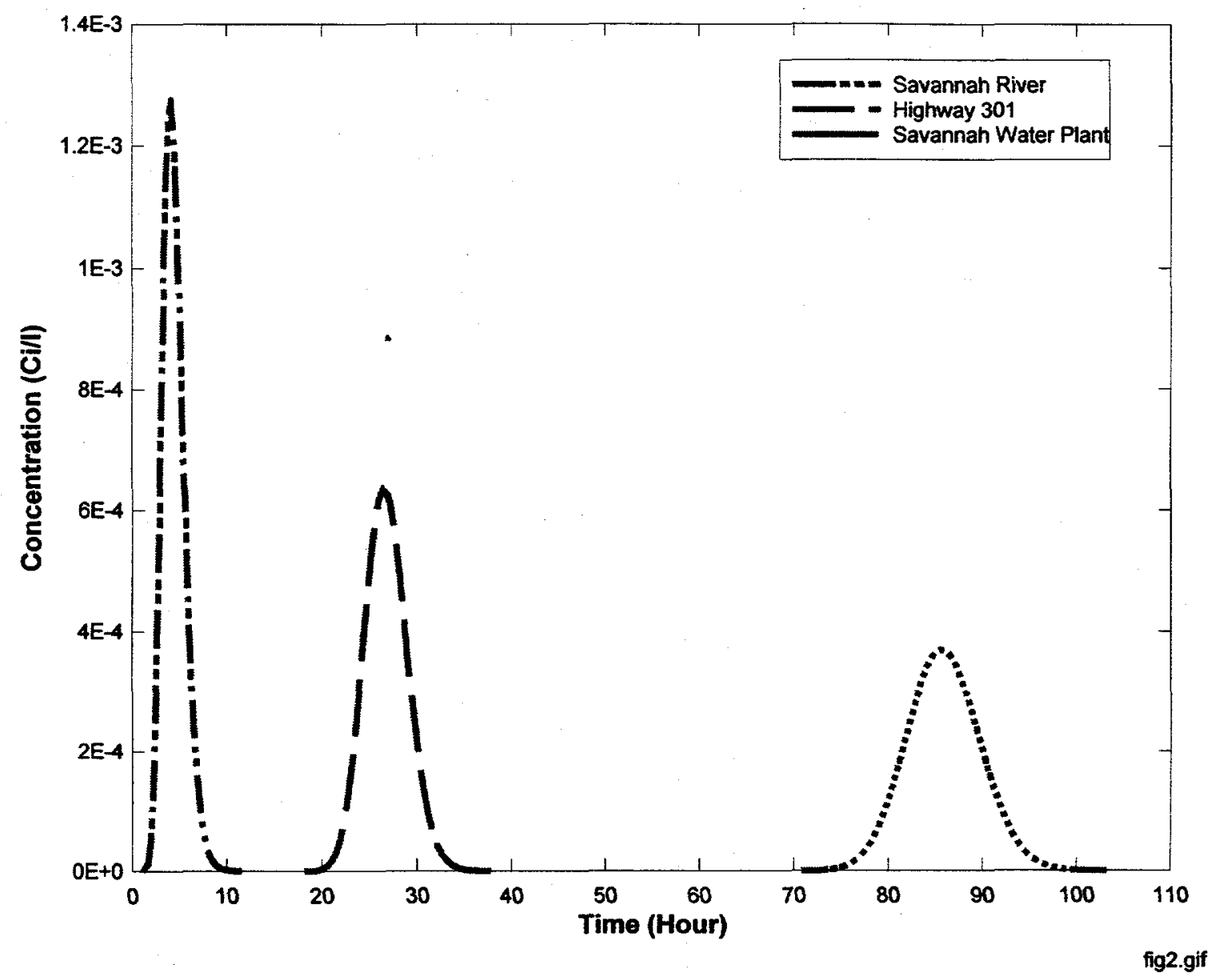


Figure 3 Calculated Tritium Concentration

\subsection{E+06 Ci Released from D-Area}

Mean Flow

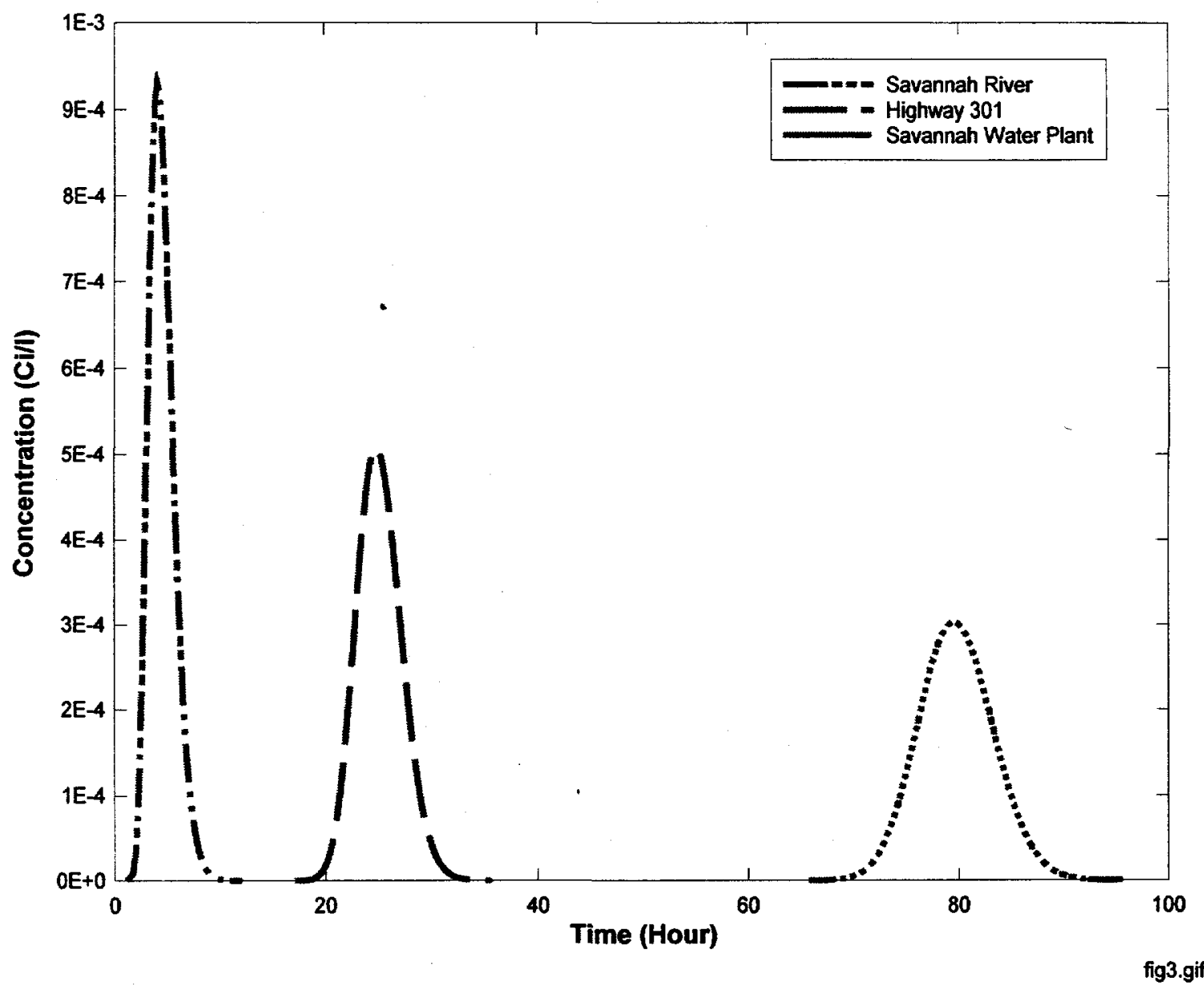


Figure 4 Calculated Tritium Concentration

\subsection{E+06 Ci Released from D-Area} Maximum Flow

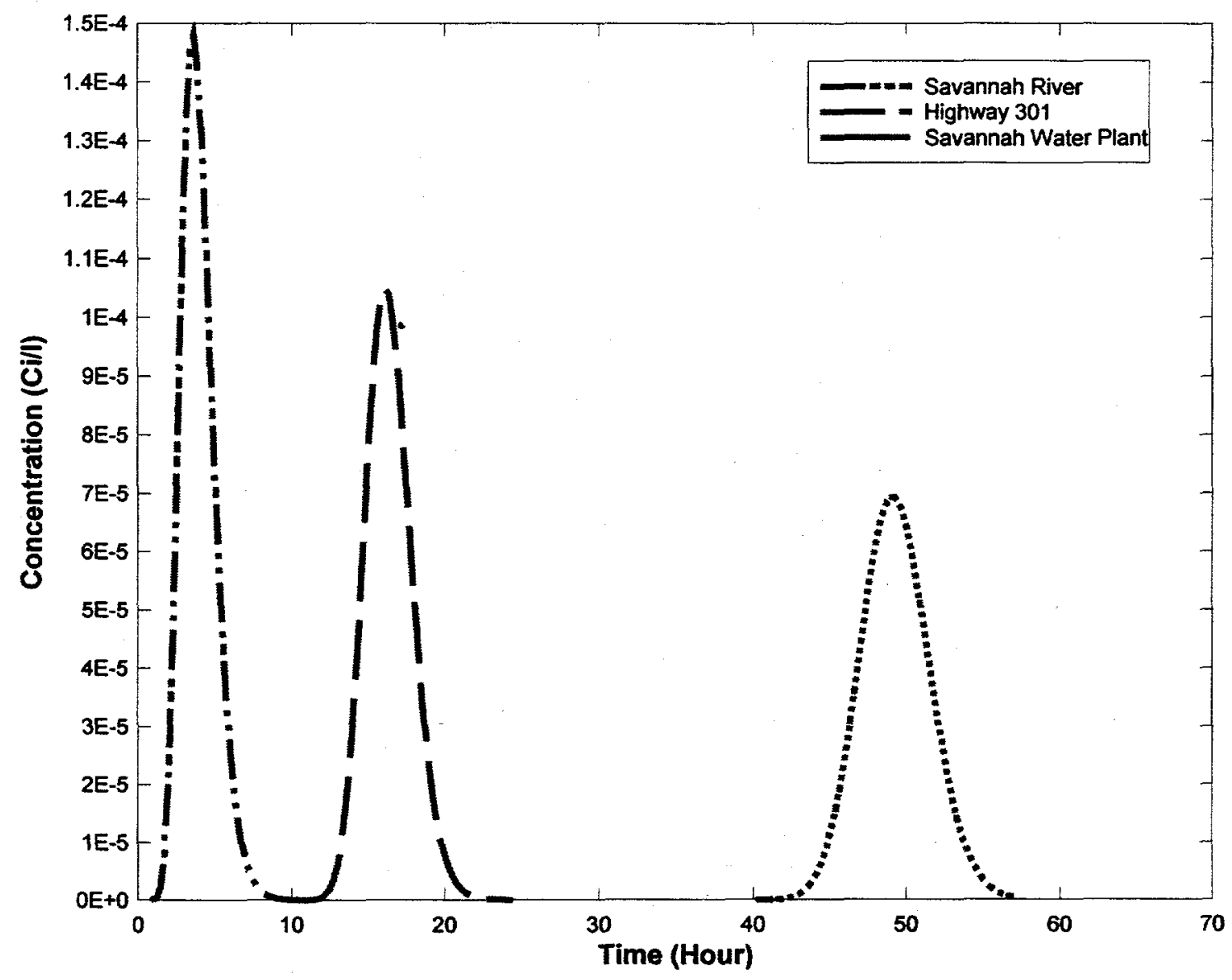


Figure 5 Calculated Concentration

\section{$1.08 \mathrm{Ci}$ Released from TNX} Minimum Flow

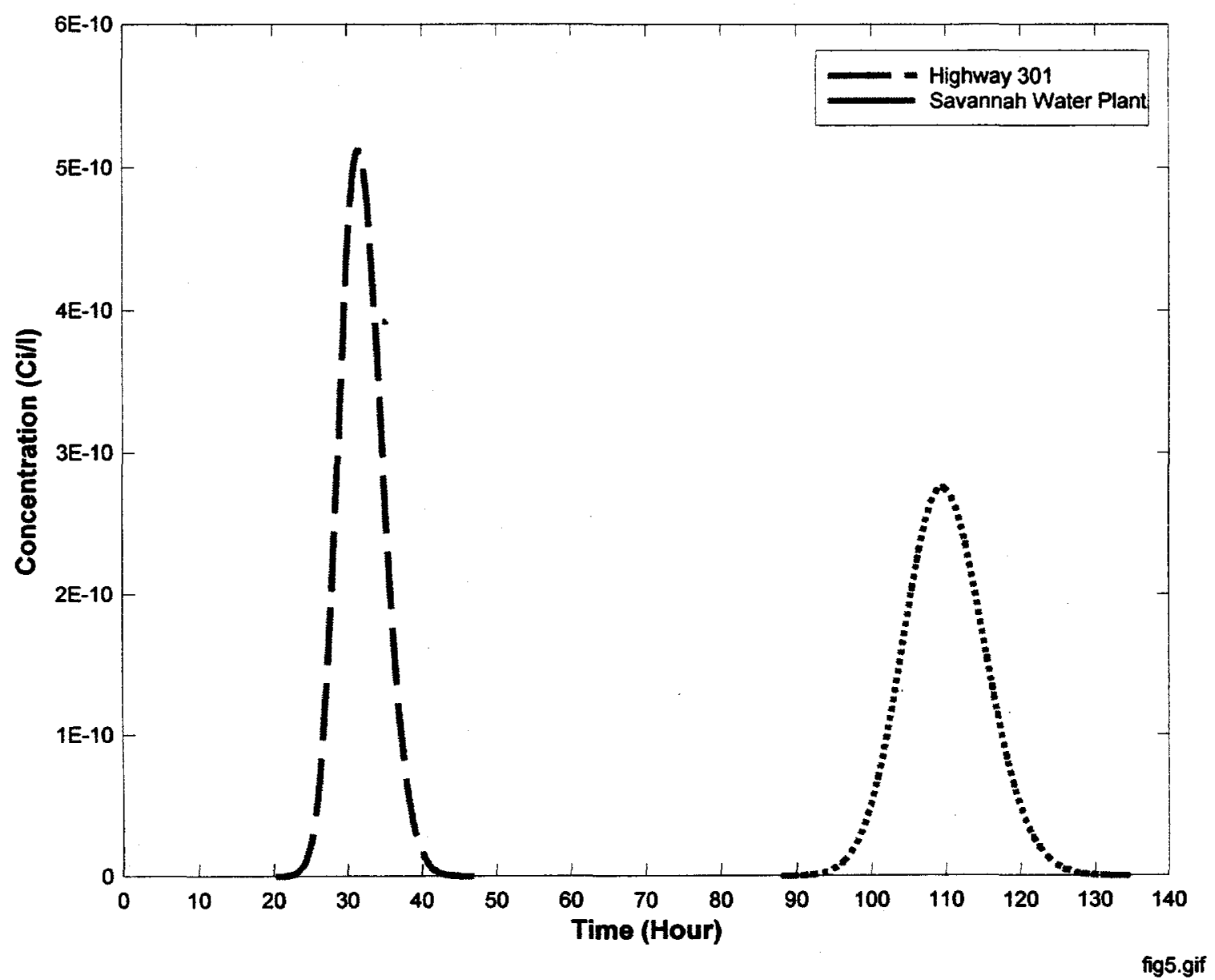


Figure 6 Calculated Concentration

1.08 Ci Released from TNX

Median Flow

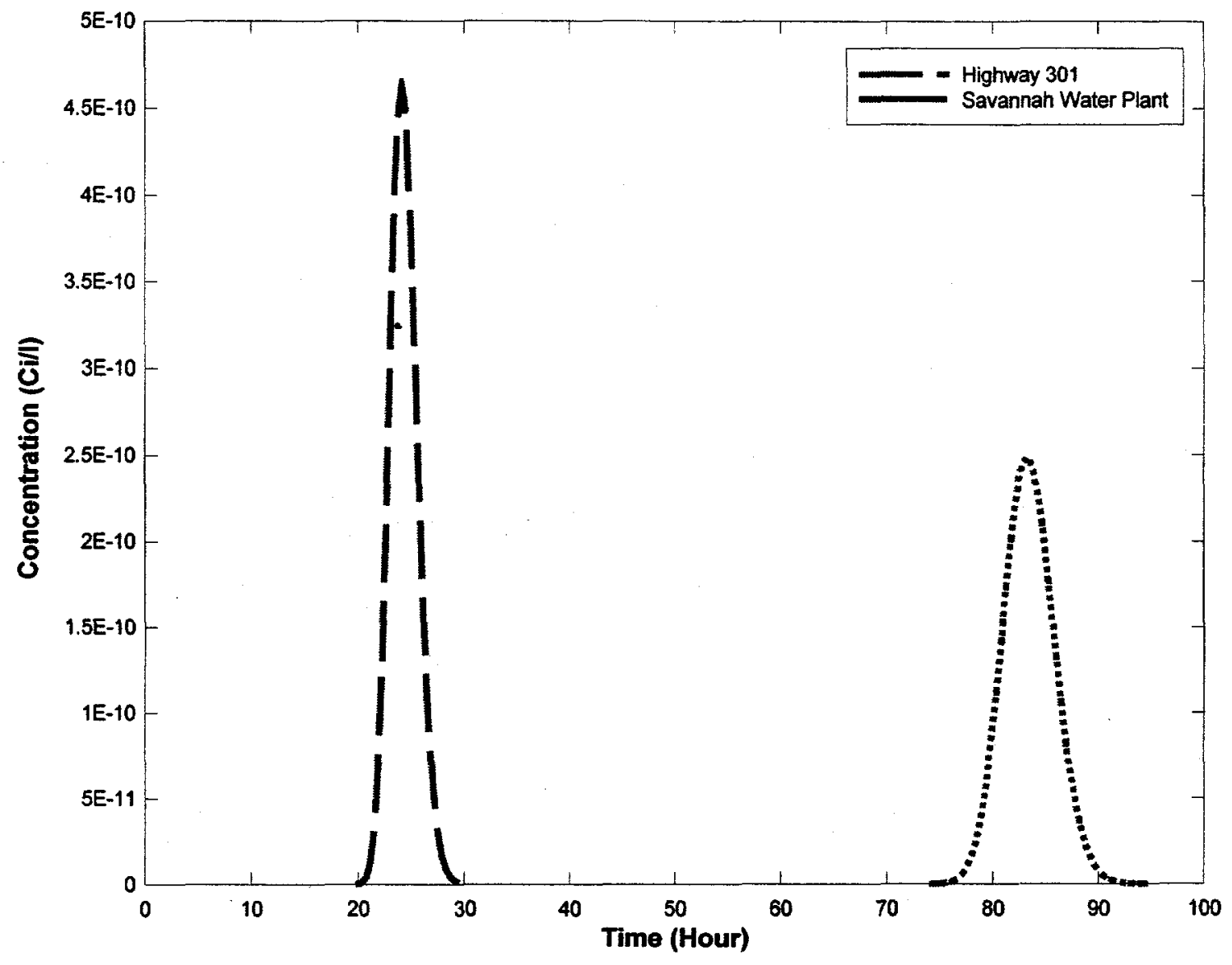

fig6.gif 
Figure 7 Calculated Concentration

\subsection{Ci Released from TNX}

Mean Flow

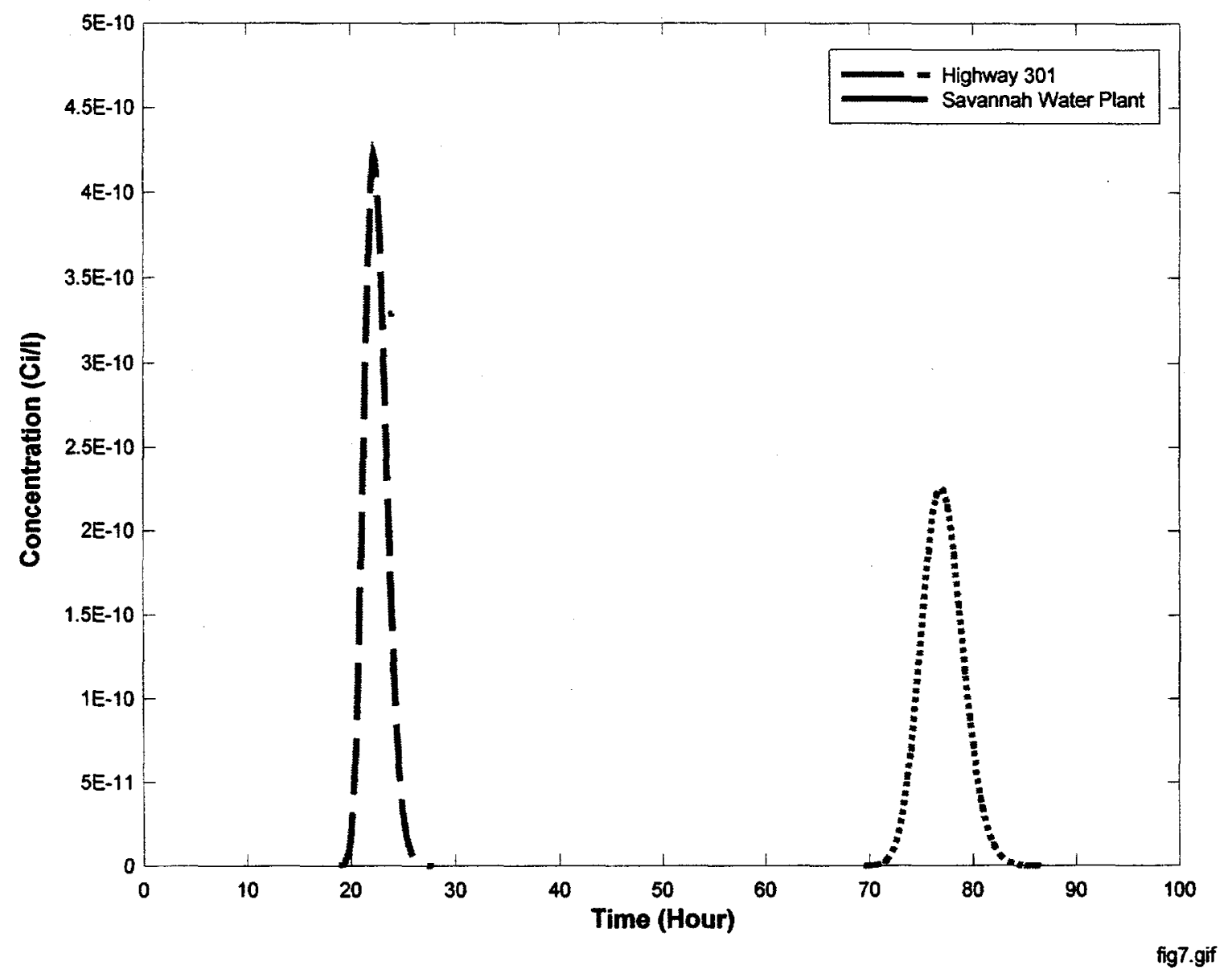




\section{Figure 8 Calculated Concentration \\ 1.08 Ci Released from TNX \\ Maximum Flow}

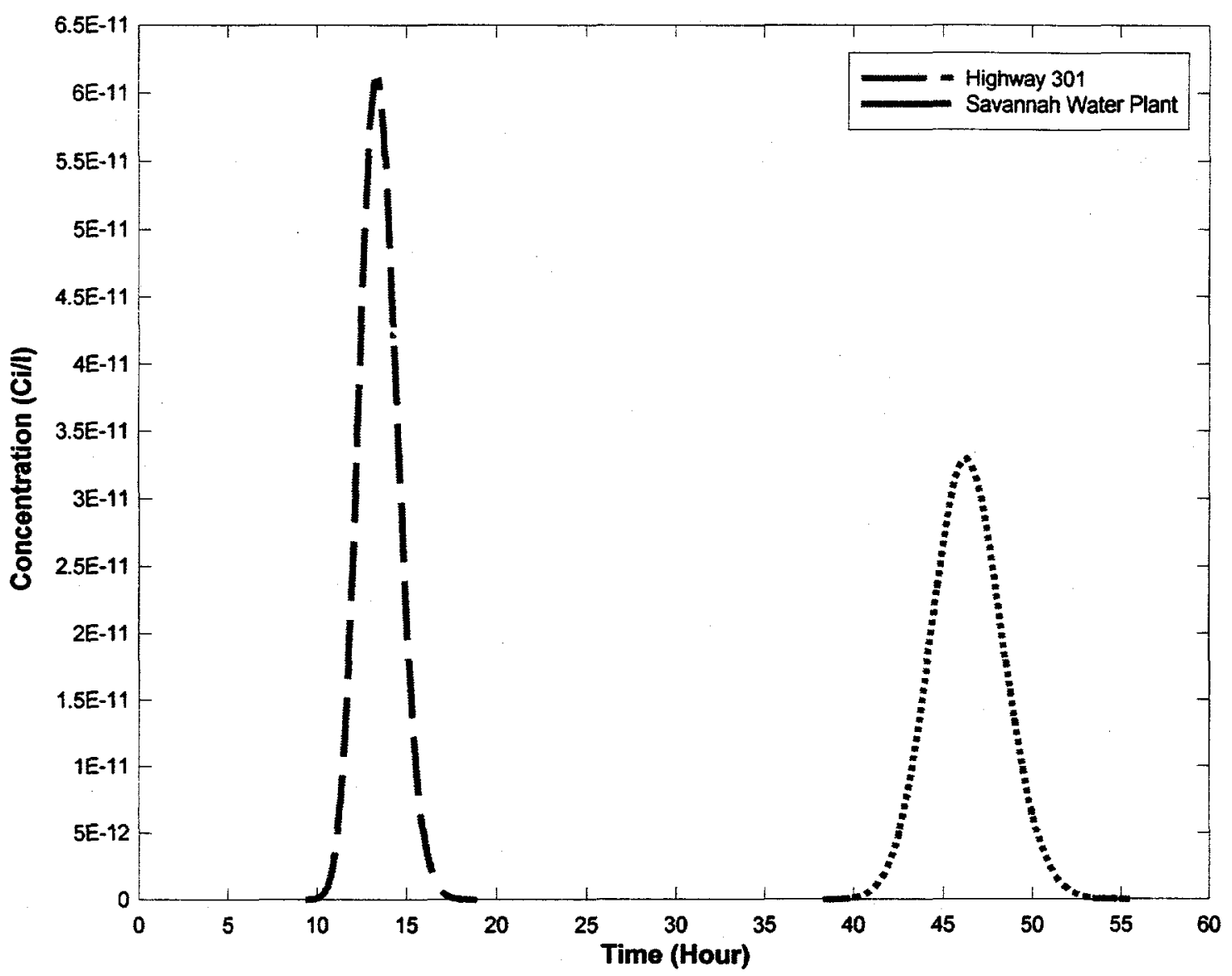

fig8.gif 
Figure 9 Calculated Concentration

\subsection{Ci Released from H-Canyon} Minimum Flow

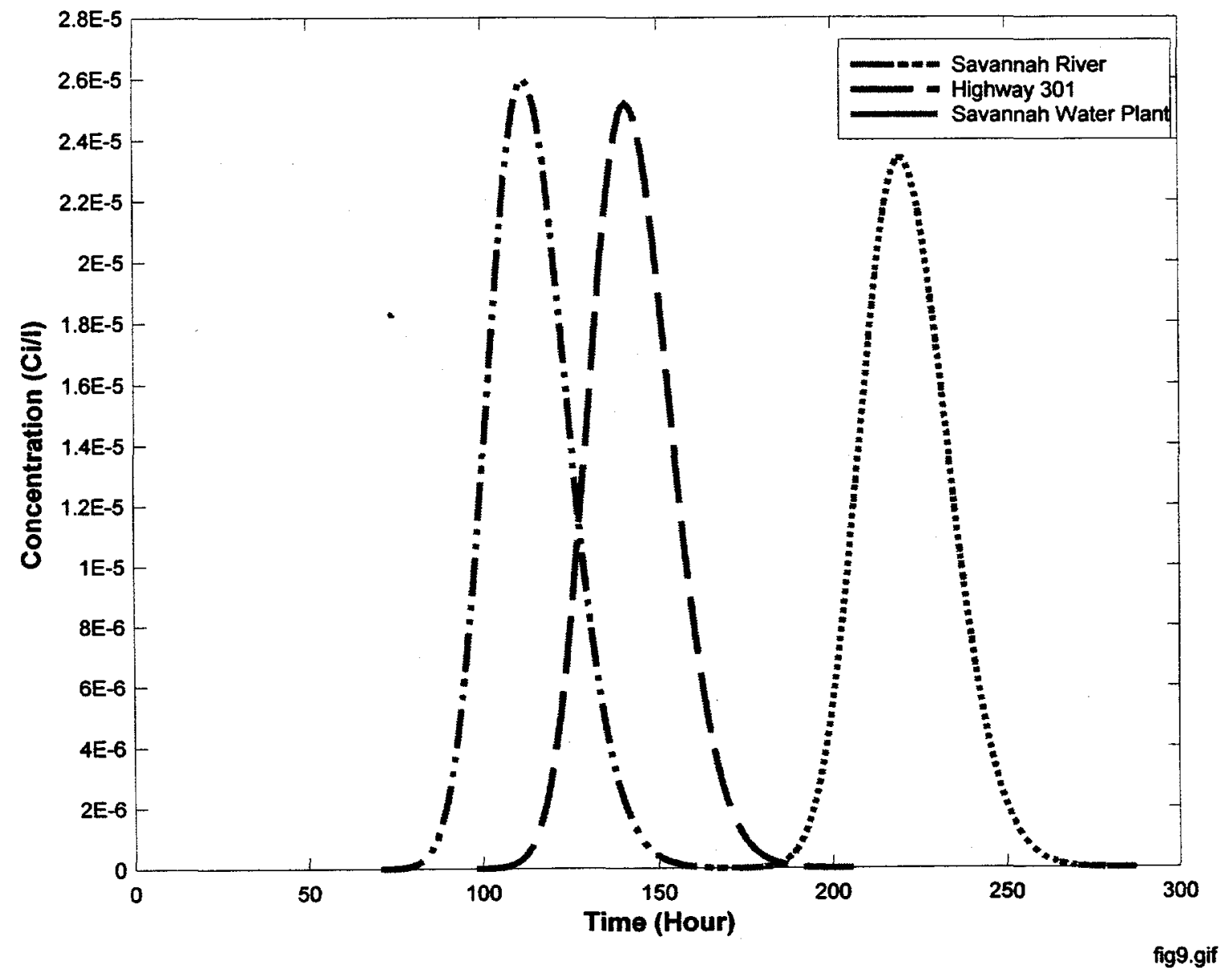


Figure 10 Calculated Concentration

211217.1546665 Ci Released from H-Canyon

Median Flow

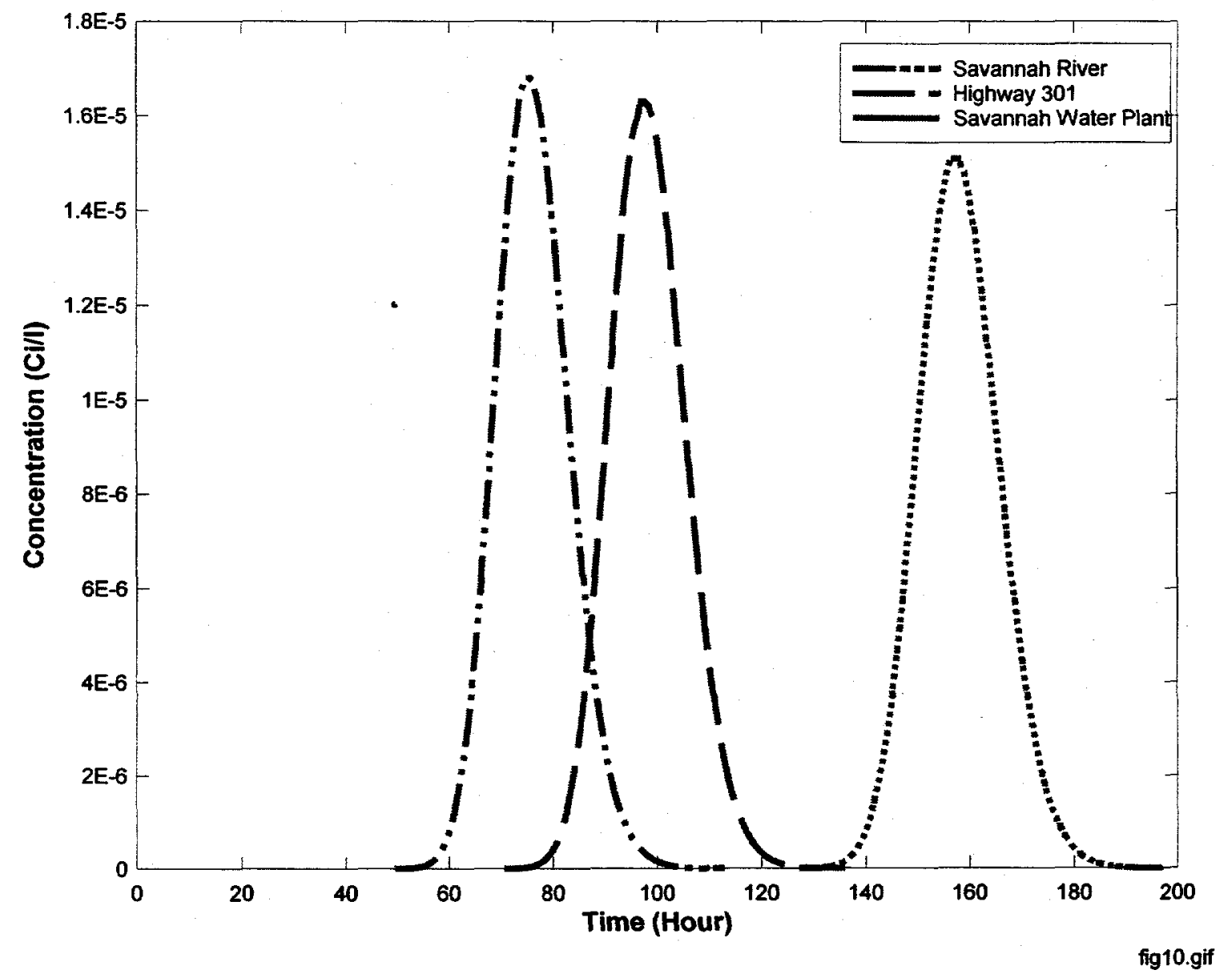


Figure 11 Calculated Concentration 211217.1546665 Ci Released from H-Canyon Mean Flow

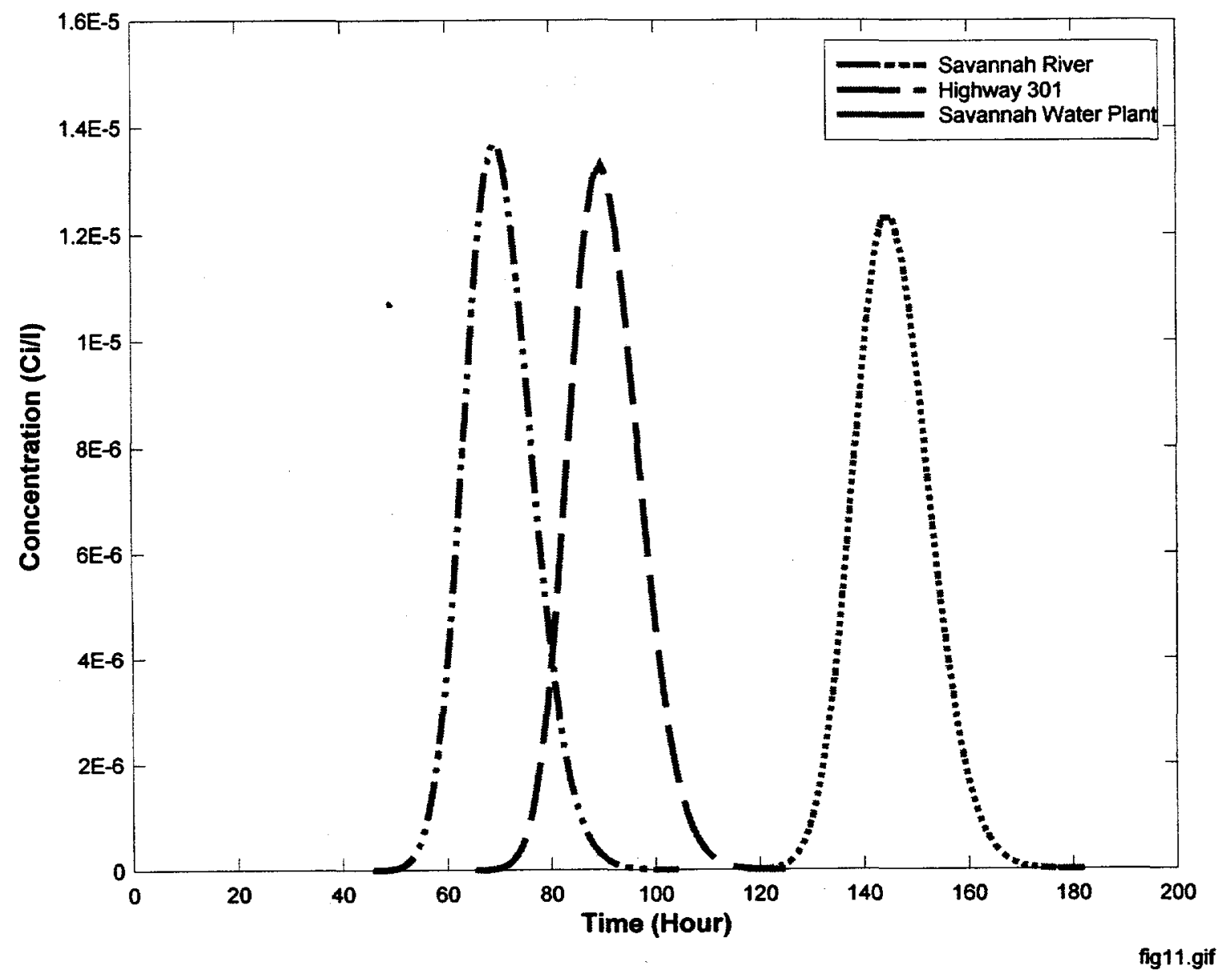


Figure 12 Calculated Concentration 211217.1546665 Ci Released from H-Canyon Maximum Flow

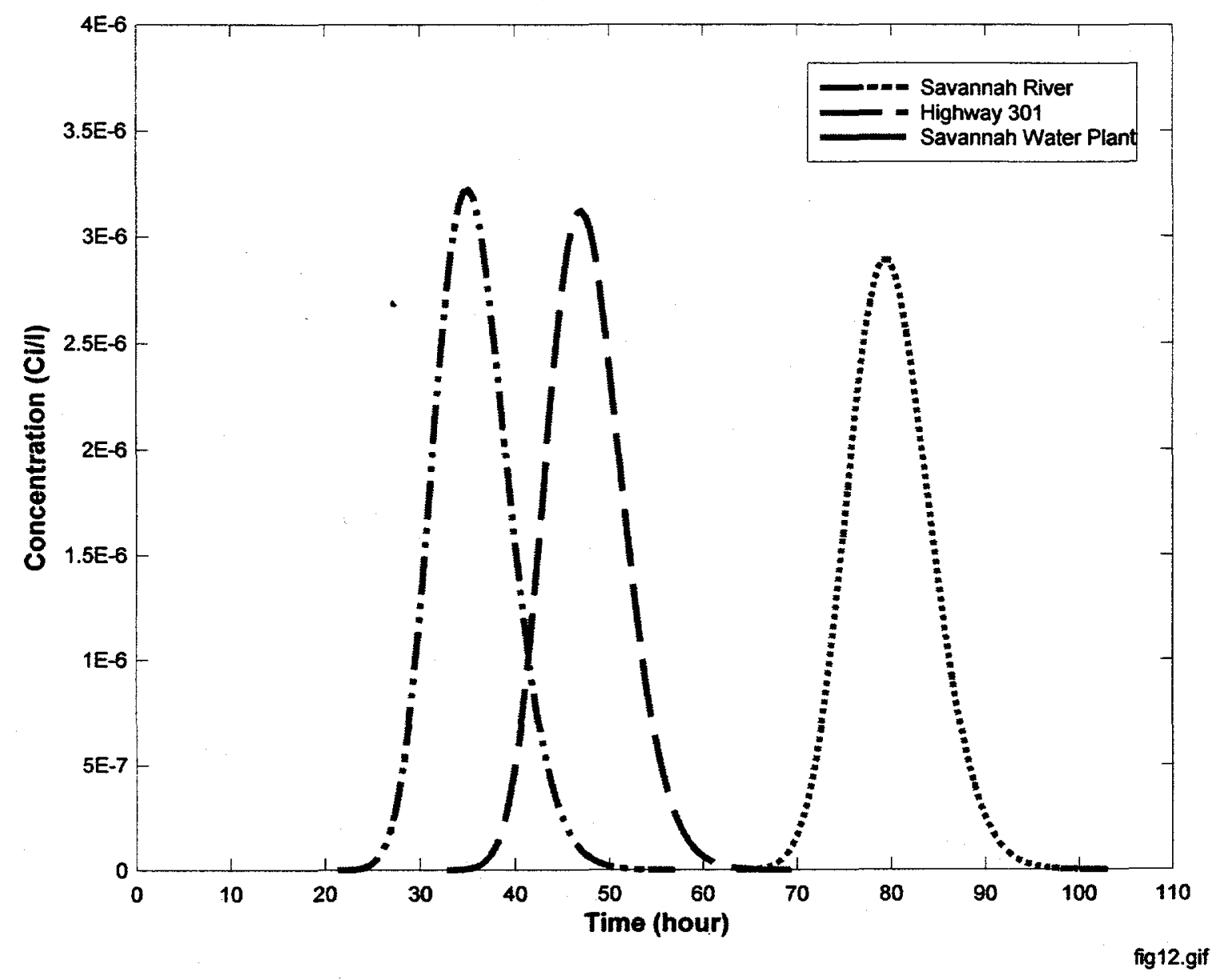




\section{Figure 13 Calculated Concentration 176512 Ci Released from H-Tank Farm Mimimum Flow}

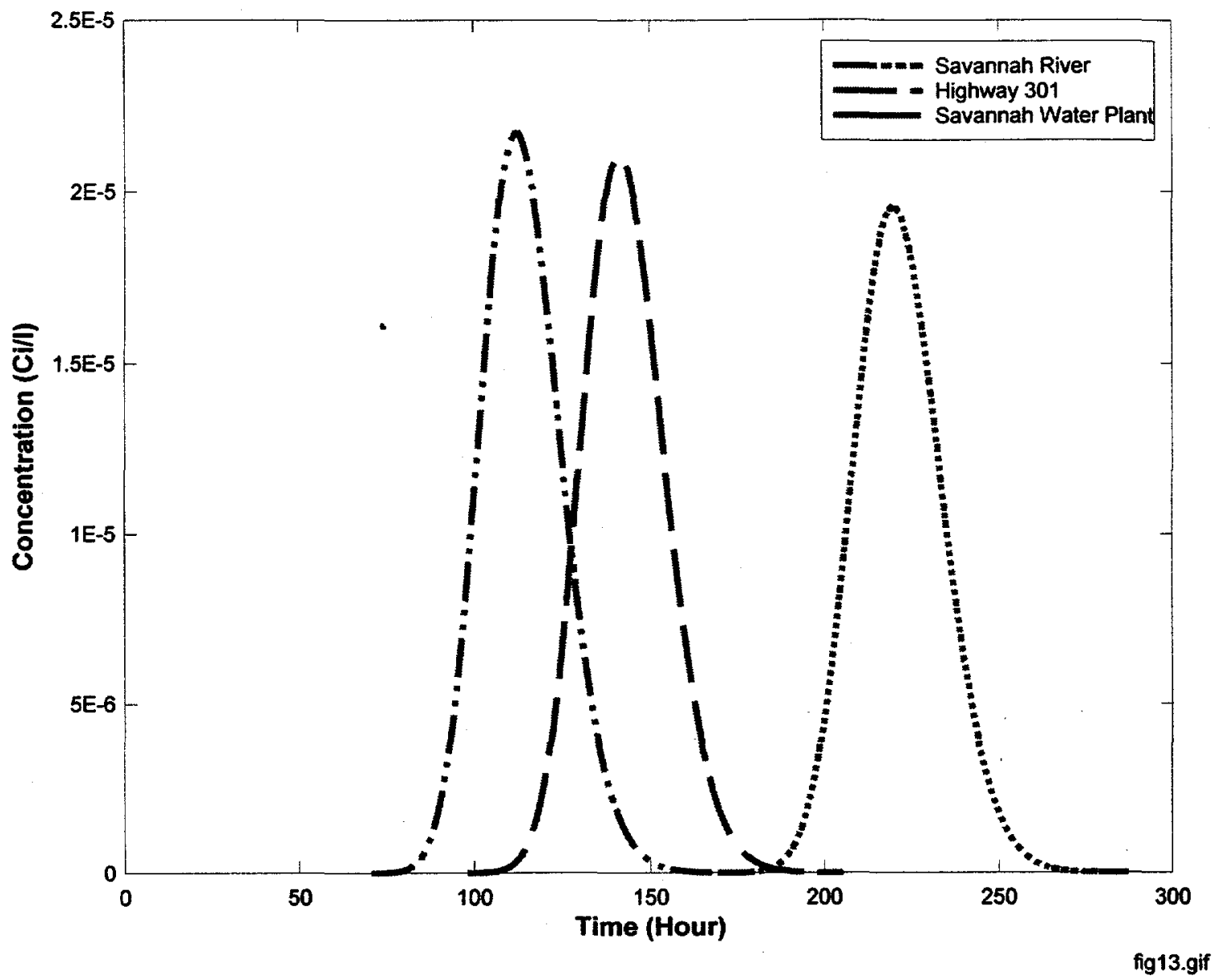


Figure 14 Calculated Concentration

$176512 \mathrm{Ci}$ Released from H-Tank Farm Median Flow

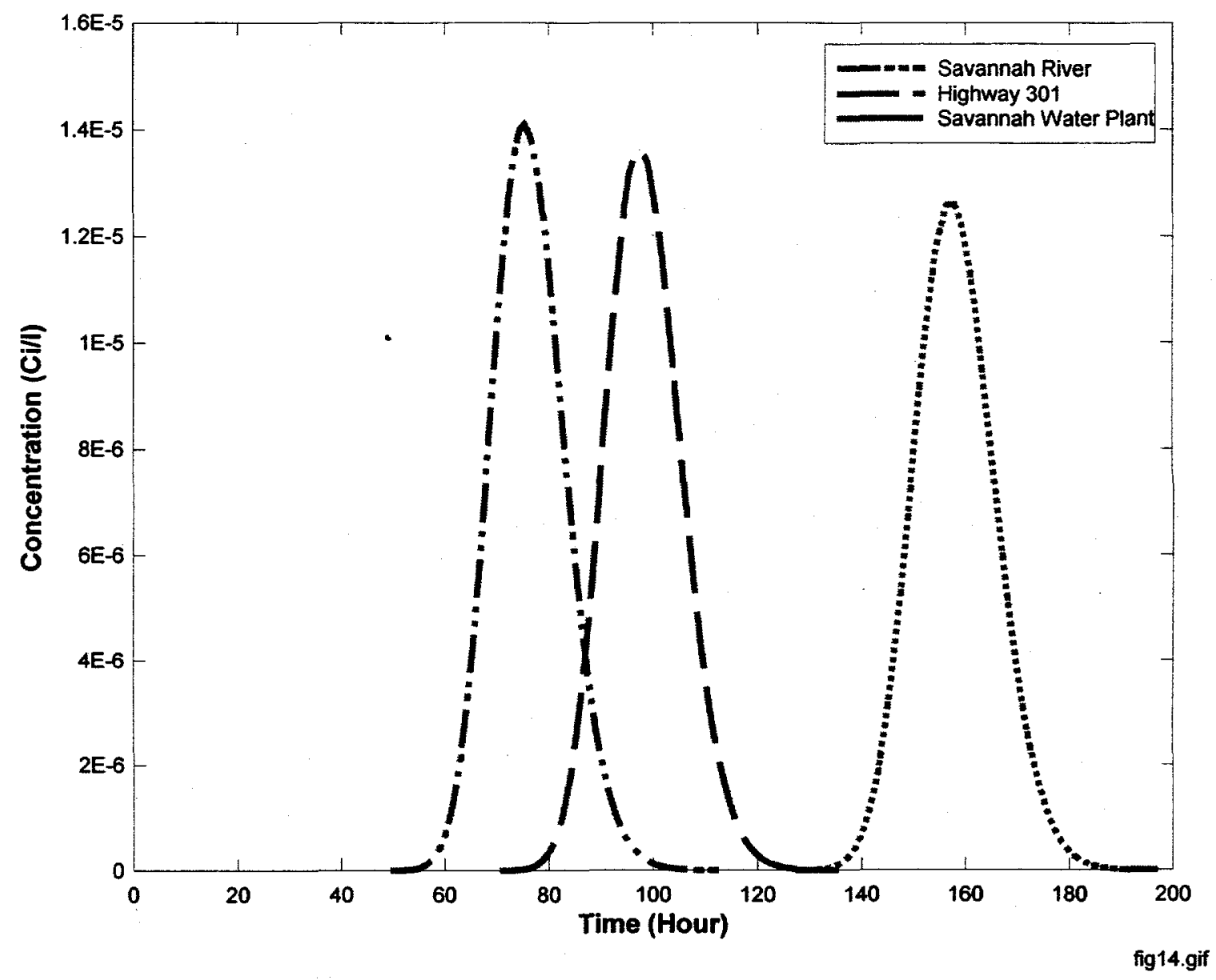


Figure 15 Calculated Concentration 176512 Ci Released from H-Tank Farm Mean Flow

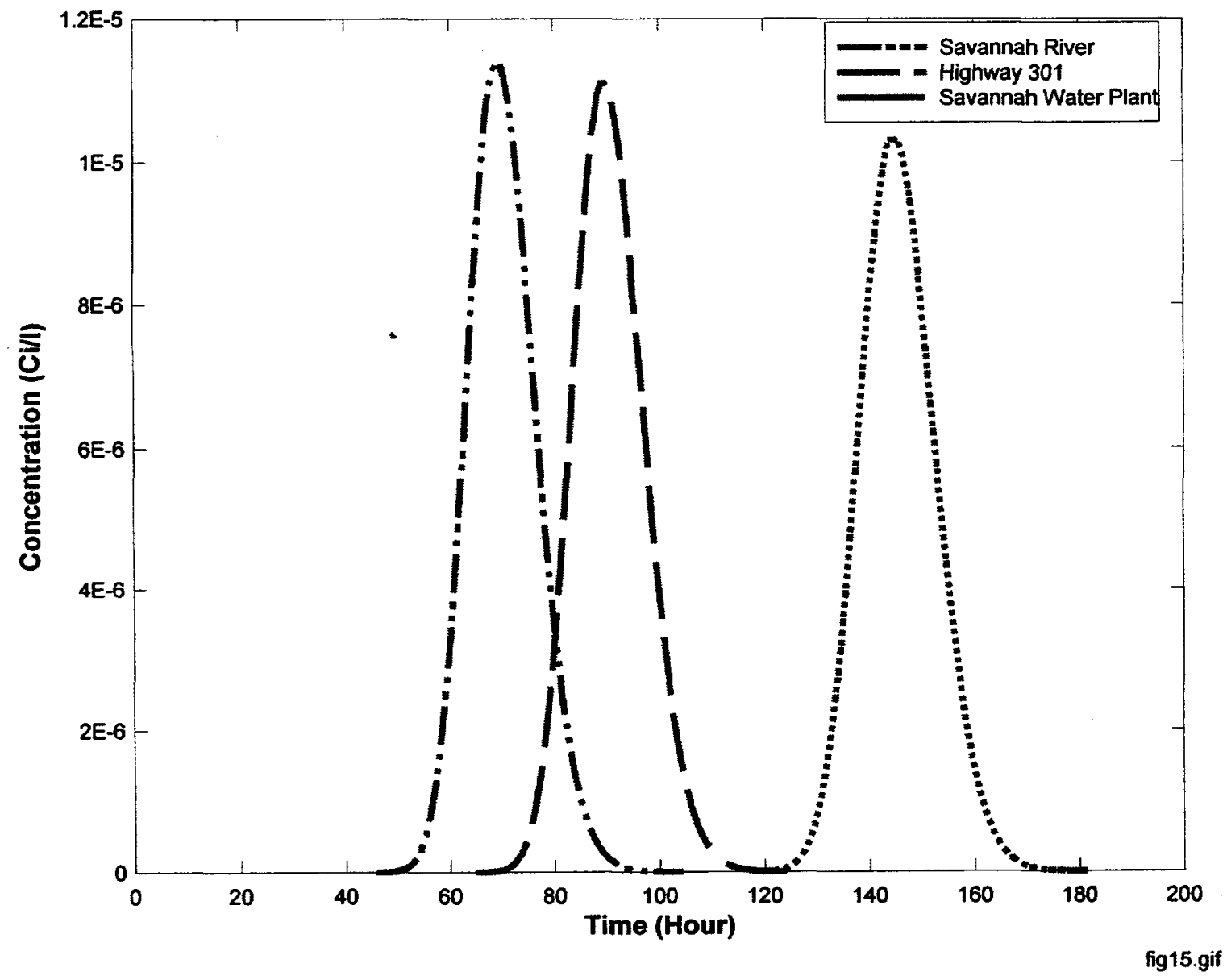




\section{Figure 16 Calculated Concentration 176512 Ci Released from H-Tank Farm Maximum Flow}

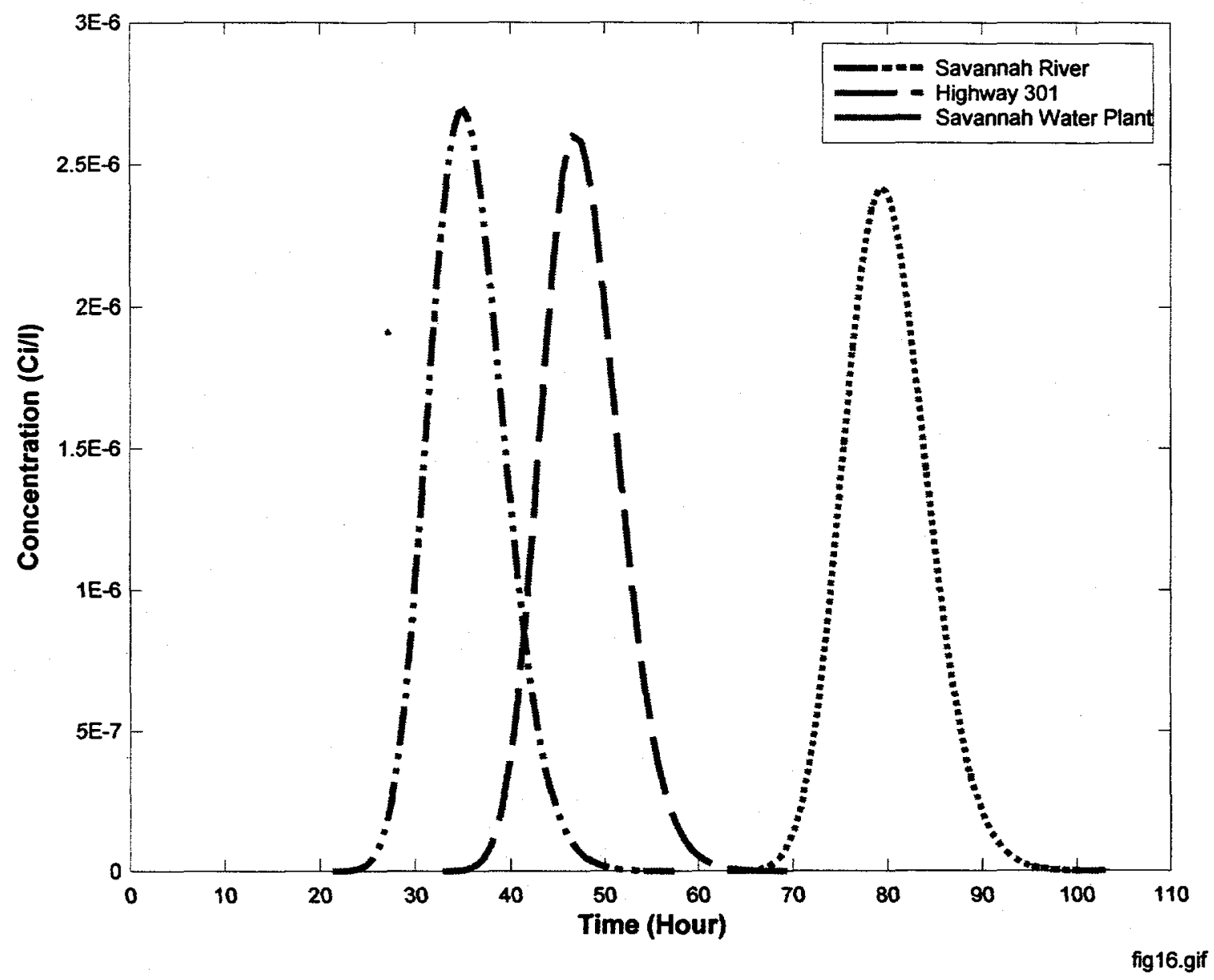




\section{APPEndix A ANnual Concentrations Resulting in EPA Standards}

\begin{tabular}{|c|c|c|c|c|c|c|c|}
\hline \multicolumn{8}{|c|}{$2 \mathrm{~L}$ per day consumption $=730 \mathrm{~L} /$ year } \\
\hline \multicolumn{8}{|c|}{ DCF Taken from EPA 520/1-88-020; FGR No. 11} \\
\hline \multicolumn{8}{|c|}{ Limiting Values of Radionuclide Intake and Air Concentration and } \\
\hline \multicolumn{8}{|c|}{ Dose Conversion Factors for Inhalation, Submersion, and Ingestion } \\
\hline & & & & & & & \\
\hline $\mathrm{Rn}$ & DCF (Sv/Bq) & DCF (rem/Ci) & Max Dose (rem) & Max Intake (Ci) & Volume (L) & MPC (Ci/L) & MPC (pCi/L) \\
\hline Sr-89 & 2.89E-08 & $1.07 E+05$ & 0.004 & $3.74 \mathrm{E}-08$ & 730 & $5.12 \mathrm{E}-11$ & $5.12 \mathrm{E}+01$ \\
\hline Sr-90 & & $0.00 \mathrm{E}+00$ & 0.004 & & 730 & & \\
\hline Y-90 & $3.16 \mathrm{E}-08$ & 1.17E+05 & 0.004 & $3.42 \mathrm{E}-08$ & 730 & 4.69E-11 & $4.69 E+01$ \\
\hline Y91 & $3.02 \mathrm{E}-08$ & $1.12 \mathrm{E}+05$ & 0.004 & 3.58E-08 & 730 & $4.90 \mathrm{E}-11$ & $4.90 \mathrm{E}+01$ \\
\hline Zr-95 & $1.02 E-09$ & $3.77 E+03$ & 0.004 & $1.06 \mathrm{E}-06$ & 730 & $1.45 E-09$ & $1.45 \mathrm{E}+03$ \\
\hline $\mathrm{Nb}-95$ & $6.95 E-10$ & $2.57 E+03$ & 0.004 & $1.56 \mathrm{E}-06$ & 730 & $2.13 E-09$ & $2.13 \mathrm{E}+03$ \\
\hline Ru-103 & $8.24 \mathrm{E}-10$ & $3.05 E+03$ & 0.004 & $1.31 \mathrm{E}-06$ & 730 & 1.80E-09 & $1.80 \mathrm{E}+03$ \\
\hline Ru-106 & $7.09 E-08$ & $2.62 E+05$ & 0.004 & $1.52 \mathrm{E}-08$ & 730 & $2.09 E-11$ & $2.09 E+01$ \\
\hline Rh-106 & & $0.00 \mathrm{E}+00$ & 0.004 & & 730 & & \\
\hline $\mathrm{Ag}-110$ & & $0.00 \mathrm{E}+00$ & 0.004 & & 730 & & \\
\hline Sn-123 & $2.59 E-08$ & $9.58 \mathrm{E}+04$ & 0.004 & $4.17 E-08$ & 730 & $5.72 E-11$ & $5.72 E+01$ \\
\hline Sb-125 & $7.57 \mathrm{E}-10$ & $2.80 \mathrm{E}+03$ & 0.004 & 1.43E-06 & 730 & $1.96 \mathrm{E}-09$ & $1.96 \mathrm{E}+03$ \\
\hline Te-127 & $7.87 \mathrm{E}-10$ & $2.91 \mathrm{E}+03$ & 0.004 & $1.37 \mathrm{E}-06$ & 730 & 1.88E-09 & $1.88 E+03$ \\
\hline Te-129 & $5.45 \mathrm{E}-11$ & $2.02 E+02$ & 0.004 & $1.98 \mathrm{E}-05$ & 730 & $2.72 E-08$ & $2.72 E+04$ \\
\hline Cs-134 & $1.98 \mathrm{E}-08$ & $7.33 E+04$ & 0.004 & $5.46 \mathrm{E}-08$ & 730 & $7.48 \mathrm{E}-11$ & $7.48 \mathrm{E}+01$ \\
\hline Cs-137 & $1.35 \mathrm{E}-08$ & $5.00 \mathrm{E}+04$ & 0.004 & $8.01 E-08$ & 730 & $1.10 \mathrm{E}-10$ & $1.10 \mathrm{E}+02$ \\
\hline $\mathrm{Ce}-141$ & 8.64E-09 & $3.20 E+04$ & 0.004 & $1.25 E-07$ & 730 & $1.71 \mathrm{E}-10$ & $1.71 E+02$ \\
\hline $\mathrm{Ce}-144$ & $6.64 E-08$ & $2.46 \mathrm{E}+05$ & 0.004 & 1.63E-08 & 730 & $2.23 E-11$ & $2.23 E+01$ \\
\hline Pr-144 & $4.09 \mathrm{E}-10$ & $1.51 \mathrm{E}+03$ & 0.004 & $2.64 E-06$ & 730 & 3.62E-09 & $3.62 \mathrm{E}+03$ \\
\hline Pm-147 & 3.17E-09 & $1.17 \mathrm{E}+04$ & 0.004 & 3.41E-07 & 730 & $4.67 E-10$ & $4.67 \mathrm{E}+02$ \\
\hline Pm-148m & $3.10 \mathrm{E}-08$ & $1.15 E+05$ & 0.004 & 3.49E-08 & 730 & $4.78 \mathrm{E}-11$ & $4.78 E+01$ \\
\hline Eu-155 & $4.13 E-10$ & $1.53 E+03$ & 0.004 & $2.62 E-06$ & 730 & $3.59 \mathrm{E}-09$ & $3.59 E+03$ \\
\hline $\mathrm{U}-234$ & $1.13 \mathrm{E}-06$ & $4.18 E+06$ & 0.004 & $9.57 \mathrm{E}-10$ & 730 & $1.31 \mathrm{E}-12$ & $1.31 E+00$ \\
\hline $\mathrm{U}-235$ & $1.05 E-06$ & $3.89 \mathrm{E}+06$ & 0.004 & 1.03E-09 & 730 & $1.41 \mathrm{E}-12$ & $1.41 \mathrm{E}+00$ \\
\hline U-236 & $1.07 \mathrm{E}-06$ & $3.96 \mathrm{E}+06$ & 0.004 & $1.01 \mathrm{E}-09$ & 730 & $1.38 \mathrm{E}-12$ & $1.38 \mathrm{E}+00$ \\
\hline U-238 & $1.01 \mathrm{E}-06$ & $3.74 \mathrm{E}+06$ & 0.004 & $1.07 \mathrm{E}-09$ & 730 & $1.47 \mathrm{E}-12$ & $1.47 \mathrm{E}+00$ \\
\hline Np-237 & $2.72 \mathrm{E}-05$ & $1.01 \mathrm{E}+08$ & 0.004 & 3.97E-11 & 730 & $5.44 \mathrm{E}-14$ & $5.44 \mathrm{E}-02$ \\
\hline $\mathrm{Pa}-233$ & $1.02 \mathrm{E}-08$ & $3.77 \mathrm{E}+04$ & 0.004 & 1.06E-07 & 730 & $1.45 \mathrm{E}-10$ & $1.45 E+02$ \\
\hline Pu-238 & $1.58 \mathrm{E}-05$ & $5.85 E+07$ & 0.004 & $6.84 \mathrm{E}-11$ & 730 & 9.37E-14 & $9.37 E-02$ \\
\hline Pu-239 & $1.76 \mathrm{E}-05$ & $6.51 \mathrm{E}+07$ & 0.004 & $6.14 \mathrm{E}-11$ & 730 & $8.41 \mathrm{E}-14$ & 8.41E-02 \\
\hline Pu240 & $1.76 \mathrm{E}-05$ & $6.51 \mathrm{E}+07$ & 0.004 & $6.14 \mathrm{E}-11$ & 730 & $8.41 \mathrm{E}-14$ & $8.41 \mathrm{E}-02$ \\
\hline Pu-241 & $3.48 \mathrm{E}-07$ & $1.29 E+06$ & 0.004 & 3.11E-09 & 730 & $4.26 \mathrm{E}-12$ & $4.26 \mathrm{E}+00$ \\
\hline $\mathrm{Pu}-242$ & 1.67E-05 & $6.18 \mathrm{E}+07$ & 0.004 & $6.47 \mathrm{E}-11$ & 730 & $8.87 E-14$ & 8.87E-02 \\
\hline Am-241 & 1.81E-05 & $6.70 \mathrm{E}+07$ & 0.004 & $5.97 E-11$ & 730 & $8.18 \mathrm{E}-14$ & $8.18 \mathrm{E}-02$ \\
\hline
\end{tabular}


Consequence Analyses Following Potential Savannah River

Site Hydrological Releases (U)

WSRC-TR-99-00108

\section{Appendix B Radionuclide Concentrations for Outfall H-12}

\begin{tabular}{|c|c|c|c|c|c|c|c|c|}
\hline & & \multicolumn{5}{|c|}{ Calculated Results for Release from H-Canyon } & & \multirow{3}{*}{ Time-Integrated } \\
\hline & & Minimum F & ow Cond & & & & & \\
\hline & & \multicolumn{6}{|c|}{ Calculated Peak Concentration and Peak Concentration Arrival Time } & \\
\hline Isotope & Discharge & \multicolumn{2}{|c|}{ Savannah River } & \multicolumn{2}{|c|}{ Highway 301} & \multicolumn{2}{|c|}{ Savannah Water Plant } & Concentration \\
\hline & Quantity (Ci) & $\mathrm{Ci} / 1$ & Hour & $\mathrm{Ci} / \mathrm{I}$ & Hour & $\mathrm{Ci} / 1$ & Hour & (Cil)hr \\
\hline Str-89 & $1.35 \mathrm{E}+04$ & $1.66 \mathrm{E}-06$ & 112.34 & $\overline{1.61 E-06}$ & 141.13 & $1.50 \mathrm{E}-06$ & 219.39 & 4.7IE-05 \\
\hline Sr-90 & $6.79 \mathrm{E}+02$ & $8.36 \mathrm{E}-08$ & & $8.10 \mathrm{E}-08$ & & $7.52 \mathrm{E}-08$ & & $2.37 \mathrm{E}-06$ \\
\hline Y-90 & $2.51 \mathrm{E}+02$ & $3.09 \mathrm{E}-08$ & & $2.99 \mathrm{E}-08$ & & $2.78 \mathrm{E}-08$ & & $8.76 \mathrm{E}-07$ \\
\hline Y91 & $2.11 \mathrm{E}+04$ & $2.60 \mathrm{E}-06$ & & $2.52 \mathrm{E}-06$ & & $2.34 \mathrm{E}-06$ & & $7.36 \mathrm{E}-05$ \\
\hline $\mathrm{Zr}-95$ & $2.70 \mathrm{E}+04$ & $3.32 \mathrm{E}-06$ & & $3.22 \mathrm{E}-06$ & & $2.99 \mathrm{E}-06$ & & $9.42 \mathrm{E}-05$ \\
\hline $\mathrm{Nb}-95$ & $4.98 \mathrm{E}+04$ & $6.13 \mathrm{E}-06$ & & 5.94E-06 & & 5.52E-06 & & $1.74 \mathrm{E}-04$ \\
\hline Ru-103 & $5.06 \mathrm{E}+03$ & 6.23E-07 & & $6.04 \mathrm{E}-07$ & & 5.61E-07 & & $1.77 \mathrm{E}-05$ \\
\hline Ru-106 & $2.60 \mathrm{E}+03$ & $3.20 \mathrm{E}-07$ & & $3.10 \mathrm{E}-07$ & & $2.88 \mathrm{E}-07$ & & $9.07 \mathrm{E}-06$ \\
\hline Rh-106 & $2.60 \mathrm{E}+03$ & $3.20 \mathrm{E}-07$ & & $3.10 \mathrm{E}-07$ & & $2.88 \mathrm{E}-07$ & & $9.07 \mathrm{E}-06$ \\
\hline Ag-110 & $7.09 \mathrm{E}+01$ & $8.73 \mathrm{E}-09$ & & $8.46 \mathrm{E}-09$ & & $7.85 \mathrm{E}-09$ & & $2.47 \mathrm{E}-07$ \\
\hline Sn-123 & $6.84 \mathrm{E}+01$ & $8.42 \mathrm{E}-09$ & & $8.16 \mathrm{E}-09$ & & $7.58 \mathrm{E}-09$ & & $2.39 \mathrm{E}-07$ \\
\hline Sb-125 & $7.76 \mathrm{E}+01$ & 9.55E-09 & & $9.26 \mathrm{E}-09$ & & $8.60 \mathrm{E}-09$ & & 2.71E-07 \\
\hline Te-127 & $1.23 \mathrm{E}+02$ & $1.51 \mathrm{E}-08$ & & 1.47E-08 & & $1.36 \mathrm{E}-08$ & & $429 \mathrm{E}-07$ \\
\hline Te-129 & $1.05 \mathrm{E}+02$ & $1.29 \mathrm{E}-08$ & & $1.25 \mathrm{E}-08$ & & $1.16 \mathrm{E}-08$ & & $3.66 \mathrm{E}-07$ \\
\hline Cs-134 & $1.68 \mathrm{E}+03$ & $2.07 \mathrm{E}-07$ & & $2.00 \mathrm{E}-07$ & & $1.86 \mathrm{E}-07$ & & $5.86 \mathrm{E}-06$ \\
\hline Cs-137 & $2.04 \mathrm{E}+03$ & $2.51 \mathrm{E}-07$ & & $2.43 \mathrm{E}-07$ & & $2.26 \mathrm{E}-07$ & & $7.12 \mathrm{E}-06$ \\
\hline $\mathrm{Ce}-141$ & $5.32 \mathrm{E}+03$ & 6.55E-07 & & $6.35 \mathrm{E}-07$ & & $5.89 \mathrm{E}-07$ & & $1.86 \mathrm{E}-05$ \\
\hline Ce-144 & $3.75 \mathrm{E}+04$ & $4.62 \mathrm{E}-06$ & & $4.47 \mathrm{E}-06$ & & 4.15E-06 & & $1.31 \mathrm{IE}-04$ \\
\hline $\begin{array}{l}\text { Pr-144 } \\
\end{array}$ & $3.75 E+04$ & $4.62 \mathrm{E}-06$ & & $4.47 \mathrm{E}-06$ & & 4.15E-06 & & $1.31 \mathrm{E}-04$ \\
\hline Pm-147 & $3.76 \mathrm{E}+03$ & 4.63E-07 & & $4.49 \mathrm{E}-07$ & & 4.17E-07 & & $1.31 \mathrm{E}-05$ \\
\hline Pm-148m & $1.03 \mathrm{E}+02$ & $1.27 \mathrm{E}-08$ & & $1.23 \mathrm{E}-08$ & & $1.14 \mathrm{E}-08$ & & $3.59 \mathrm{E}-07$ \\
\hline Eu-155 & $4.18 \mathrm{E}+01$ & 5.15E-09 & & $4.99 \mathrm{E}-09$ & & 4.63E-09 & & $1.46 \mathrm{E}-07$ \\
\hline $\bar{U}-234$ & $1.16 \mathrm{E}-01$ & $1.43 \mathrm{E}-11$ & & $1.38 \mathrm{E}-11$ & & $129 \mathrm{E}-11$ & & $4.05 \mathrm{E}-10$ \\
\hline U-235 & $1.01 \mathrm{E}-03$ & $1.24 \mathrm{E}-13$ & & $1.21 \mathrm{E}-13$ & & $1.12 \mathrm{E}-13$ & & $3.52 \mathrm{E}-12$ \\
\hline U-236 & $3.22 \mathrm{E}-02$ & $3.96 \mathrm{E}-12$ & & $3.84 \mathrm{E}-12$ & & $3.57 \mathrm{E}-12$ & & $1.12 \mathrm{E}-10$ \\
\hline U-238 & $8.65 \mathrm{E}-05$ & $1.06 \mathrm{E}-14$ & & $1.03 \mathrm{E}-14$ & & $9.58 \mathrm{E}-15$ & & $3.02 \mathrm{E}-13$ \\
\hline Np-237 & $2.19 \mathrm{E}-02$ & $2.70 \mathrm{E}-12$ & & $2.61 \mathrm{E}-12$ & & $2.43 \mathrm{E}-12$ & & $7.64 \mathrm{E}-11$ \\
\hline Pa-233 & $0.00 E+00$ & $0.00 \mathrm{E}+00$ & & $0.00 E+00$ & & $0.00 \mathrm{E}+00$ & & $0.00 E+00$ \\
\hline Pu-238 & $1.02 \mathrm{E}+02$ & $1.26 \mathrm{E}-08$ & & $1.22 \mathrm{E}-08$ & & $1.13 \mathrm{E}-08$ & & $3.56 \mathrm{E}-07$ \\
\hline Pu-239 & 4.56E-01 & $5.61 \mathrm{E}-11$ & & $5.44 \mathrm{E}-11$ & & 5.05E-11 & & $1.59 \mathrm{E}-09$ \\
\hline Pu240 & $1.56 \mathrm{E}-01$ & $1.92 \mathrm{E}-11$ & & $1.86 \mathrm{E}-11$ & & $1.73 \mathrm{E}-11$ & & $5.44 \mathrm{E}-10$ \\
\hline Pu-241 & $1.32 \mathrm{E}+02$ & $1.62 \mathrm{E}-08$ & & $1.57 \mathrm{E}-08$ & & $1.46 \mathrm{E}-08$ & & $4.61 \mathrm{IE}-07$ \\
\hline Pu-242 & $1.47 \mathrm{E}-03$ & $1.81 \mathrm{E}-13$ & & $1.75 \mathrm{E}-13$ & & $1.63 \mathrm{E}-13$ & & $5.13 \mathrm{E}-12$ \\
\hline Am-241 & $2.67 \mathrm{E}+00$ & $3.29 \mathrm{E}-10$ & & $3.19 \mathrm{E}-10$ & & $2.96 \mathrm{E}-10$ & & $9.32 \mathrm{E}-09$ \\
\hline Total & 211217.1546665 & $2.60 \mathrm{E}-05$ & & $2.52 \mathrm{E}-05$ & & $2.34 \mathrm{E}-05$ & & $7.37 \mathrm{E}-04$ \\
\hline
\end{tabular}




\begin{tabular}{|c|c|c|c|c|c|c|c|c|}
\hline & & Calculated Resu & ults for $F$ & ease from & $\mathrm{H}-\mathrm{Ca}$ & nyon & & \\
\hline & & & Median F & Condition & & & & \\
\hline & & & & & & & & \\
\hline & & Calculated & Peak Conc & ration and $\mathrm{Pe}$ & ak Conc & entration Arriv & Time & Time-Integrated \\
\hline Isotope & Discharge & Savanna & h River & Highway 3 & & Savannah Wat & r Plant & Concentration \\
\hline & Quantity (Ci) & $\mathrm{Ci}$ & Hour & $\mathrm{Ci} / 1$ & Hour & $\mathrm{Ci}$ I & Hour & (Ci/l)hr \\
\hline Sr-89 & $1.35 \mathrm{E}+04$ & $1.07 \mathrm{E}-06$ & 74.95 & $1.04 \mathrm{E}-06$ & 97.03 & $9.65 \mathrm{E}-07$ & 156.50 & $1.88 \mathrm{E}-05$ \\
\hline Sr-90 & $6.79 \mathrm{E}+02$ & $5.40 \mathrm{E}-08$ & & $5.24 \mathrm{E}-08$ & & $4.85 \mathrm{E}-08$ & & 9.45E-07 \\
\hline Y-90 & $2.51 \mathrm{E}+02$ & $2.00 \mathrm{E}-08$ & & $1.94 \mathrm{E}-08$ & & $1.79 \mathrm{E}-08$ & & $3.49 \mathrm{E}-07$ \\
\hline Y91 & $2.11 \mathrm{E}+04$ & $1.68 \mathrm{E}-06$ & & $1.63 \mathrm{E}-06$ & & $1.51 \mathrm{E}-06$ & & $2.94 E-05$ \\
\hline $2 r-95$ & $2.70 \mathrm{E}+04$ & $2.15 \mathrm{E}-06$ & & $2.08 \mathrm{E}-06$ & & $1.93 \mathrm{E}-06$ & & $3.76 \mathrm{E}-05$ \\
\hline Nb-95 & $4.98 \mathrm{E}+04$ & $3.96 \mathrm{E}-06$ & & $3.84 \mathrm{E}-06$ & & $3.56 \mathrm{E}-06$ & & $6.93 \mathrm{E}-05$ \\
\hline$R \mathrm{R}-103$ & $5.06 \mathrm{E}+03$ & $4.02 \mathrm{E}-07$ & & $3.90 \mathrm{E}-07$ & & $3.62 \mathrm{E}-07$ & & $7.04 \mathrm{E}-06$ \\
\hline Ru-106 & $2.60 \mathrm{E}+03$ & $2.07 \mathrm{E}-07$ & & $2.01 \mathrm{E}-07$ & & $1.86 \mathrm{E}-07$ & & $3.62 \mathrm{E}-06$ \\
\hline$\longdiv { R h - 1 0 6 }$ & $2.60 E+03$ & $2.07 \mathrm{E}-07$ & & $2.01 E-07$ & & $1.86 E-07$ & & $3.62 \mathrm{E}-06$ \\
\hline$\overline{\mathrm{Ag}-110}$ & $7.09 \mathrm{E}+01$ & $5.64 \mathrm{E}-09$ & & 5.47E-09 & & $5.07 \mathrm{E}-09$ & & $9.87 \mathrm{E}-08$ \\
\hline Sn-123 & $6.84 \mathrm{E}+01$ & $5.44 \mathrm{E}-09$ & & $5.28 \mathrm{E}-09$ & & $4.89 \mathrm{E}-09$ & & $9.52 \mathrm{E}-08$ \\
\hline Sb-125 & $7.76 \mathrm{E}+01$ & $6.17 \mathrm{E}-09$ & & $5.99 \mathrm{E}-09$ & & $5.55 \mathrm{E}-09$ & & $1.08 \mathrm{E}-07$ \\
\hline Te-127 & $1.23 \mathrm{E}+02$ & $9.78 \mathrm{E}-09$ & & $9.49 \mathrm{E}-09$ & & $8.79 \mathrm{E}-09$ & & $1.71 \mathrm{E}-07$ \\
\hline Te-129 & $1.05 \mathrm{E}+02$ & $8.35 \mathrm{E}-09$ & & $8.10 \mathrm{E}-09$ & & $7.51 \mathrm{E}-09$ & & $1.46 \mathrm{E}-07$ \\
\hline Cs-134 & $1.68 \mathrm{E}+03$ & $1.34 \mathrm{E}-07$ & & $1.30 \mathrm{E}-07$ & & $1.20 \mathrm{E}-07$ & & $2.34 \mathrm{E}-06$ \\
\hline Cs-137 & $2.04 E+03$ & $1.62 \mathrm{E}-07$ & & $1.57 \mathrm{E}-07$ & & $1.46 \mathrm{E}-07$ & & $2.84 \mathrm{E}-06$ \\
\hline$\overline{\mathrm{Ce}-141}$ & $5.32 \mathrm{E}+03$ & $4.23 \mathrm{E}-07$ & & 4.11E-07 & & $3.80 \mathrm{E}-07$ & & $7.41 \mathrm{E}-06$ \\
\hline $\mathrm{Ce}-144$ & $3.75 \mathrm{E}+04$ & $2.98 \mathrm{E}-06$ & & $2.89 \mathrm{E}-06$ & & $2.68 \mathrm{E}-06$ & & $5.22 \mathrm{E}-05$ \\
\hline$\overline{P r-144}$ & $3.75 E+04$ & $2.98 \mathrm{E}-06$ & & $2.89 \mathrm{E}-06$ & & $2.68 \mathrm{E}-06$ & & $5.22 \mathrm{E}-05$ \\
\hline Pm-147 & $3.76 \mathrm{E}+03$ & $2.99 \mathrm{E}-07$ & & $2.90 \mathrm{E}-07$ & & $2.69 \mathrm{E}-07$ & & $5.23 \mathrm{E}-06$ \\
\hline Pm-148m & $1.03 \mathrm{E}+02$ & $8.19 \mathrm{E}-09$ & & $7.95 \mathrm{E}-09$ & & $7.36 \mathrm{E}-09$ & & $1.43 \mathrm{E}-07$ \\
\hline Eu-155 & $4.18 \mathrm{E}+01$ & $3.32 \mathrm{E}-09$ & & $3.23 \mathrm{E}-09$ & & $2.99 \mathrm{E}-09$ & & $5.82 \mathrm{E}-08$ \\
\hline U-234 & $1.16 \mathrm{E}-01$ & $9.23 \mathrm{E}-12$ & & $8.95 \mathrm{E}-12$ & & $8.29 \mathrm{E}-12$ & & $1.61 \mathrm{E}-10$ \\
\hline U-235 & $1.01 \mathrm{E}-03$ & $8.03 \mathrm{E}-14$ & & $7.79 \mathrm{E}-14$ & & $7.22 \mathrm{E}-14$ & & $1.41 \mathrm{E}-12$ \\
\hline U-236 & $3.22 \mathrm{E}-02$ & $2.56 \mathrm{E}-12$ & & $2.48 E-12$ & & $2.30 \mathrm{E}-12$ & & $4.48 \mathrm{E}-11$ \\
\hline U-238 & $8.65 \mathrm{E}-05$ & $6.88 \mathrm{E}-15$ & & $6.68 \mathrm{E}-15$ & & $6.18 \mathrm{E}-15$ & & $1.20 \mathrm{E}-13$ \\
\hline Np-237 & $2.19 \mathrm{E}-02$ & $1.74 \mathrm{E}-12$ & & $1.69 \mathrm{E}-12$ & & $1.57 \mathrm{E}-12$ & & $3.05 \mathrm{E}-11$ \\
\hline $\mathrm{Pa}-233$ & $0.00 \mathrm{E}+00$ & $0.00 \mathrm{E}+00$ & & $0.00 \mathrm{E}+00$ & & $0.00 \mathrm{E}+00$ & & $0.00 \mathrm{E}+00$ \\
\hline Pu-238 & $1.02 E+02$ & 8.11E-09 & & $7.87 \mathrm{E}-09$ & & $7.29 \mathrm{E}-09$ & & $1.42 \mathrm{E}-07$ \\
\hline Pu-239 & $4.56 \mathrm{E}-01$ & $3.63 \mathrm{E}-11$ & & $3.52 \mathrm{E}-11$ & & $3.26 \mathrm{E}-11$ & & $6.35 \mathrm{E}-10$ \\
\hline$\overline{P u 240}$ & $1.56 \mathrm{E}-01$ & $1.24 \mathrm{E}-11$ & & $1.20 \mathrm{E}-11$ & & $1.12 \mathrm{E}-11$ & & $2.17 \mathrm{E}-10$ \\
\hline$\overline{\mathrm{Pu}-241}$ & $132 \mathrm{E}+02$ & $1.05 \mathrm{E}-08$ & & $1.02 \mathrm{E}-08$ & & $9.44 \mathrm{E}-09$ & & $1.84 \mathrm{E}-07$ \\
\hline Pu-242 & $1.47 \mathrm{E}-03$ & $1.17 \mathrm{E}-13$ & & $1.13 \mathrm{E}-13$ & & $1.05 \mathrm{E}-13$ & & $2.05 \mathrm{E}-12$ \\
\hline$\overline{\mathrm{Am}-241}$ & $2.67 \mathrm{E}+00$ & $2.12 \mathrm{E}-10$ & & $2.06 \mathrm{E}-10$ & & $1.91 \mathrm{E}-10$ & & $3.72 \mathrm{E}-09$ \\
\hline Total & 211217.1546665 & $1.68 \mathrm{E}-05$ & & $1.63 \mathrm{E}-05$ & & $1.51 \mathrm{E}-05$ & & $2.94 \mathrm{E}-04$ \\
\hline
\end{tabular}




\begin{tabular}{|c|c|c|c|c|c|c|c|c|}
\hline & & \multicolumn{6}{|c|}{ Calculated Results for Release from H-Canyon } & \multirow{4}{*}{$\begin{array}{c}\text { Time-Integrated } \\
\text { Concentration }\end{array}$} \\
\hline & & & Mean Flo & Condition & & & & \\
\hline & & \multicolumn{6}{|c|}{ Calculated Peak Concentration and Peak Concentration Arrival Time } & \\
\hline Isotope & Discharge & \multicolumn{2}{|c|}{ Savannah River } & \multicolumn{2}{|c|}{ Highway 301} & \multicolumn{2}{|c|}{ Savannah Water Plant } & \\
\hline & Quantity (Ci) & $\mathrm{Ci} / 1$ & Hour & $\overline{\mathrm{Ci}}$ & Hour & $\mathrm{Ci} / 1$ & Hour & (Cil)hr \\
\hline & & & & & & & & \\
\hline Sr-89 & $1.35 \mathrm{E}+04$ & 8.76E-07 & 69.16 & $8.50 \mathrm{E}-07$ & 89.82 & $7.86 \mathrm{E}-07$ & 144.07 & $1.41 \mathrm{E}-05$ \\
\hline Sr-90 & $6.79 \mathrm{E}+02$ & $4.40 \mathrm{E}-08$ & & 4.28E-08 & & $3.95 \mathrm{E}-08$ & & $7.07 \mathrm{E}-07$ \\
\hline Y-90 & $2.51 \mathrm{E}+02$ & $1.63 \mathrm{E}-08$ & & $1.58 \mathrm{E}-08$ & & $1.46 \mathrm{E}-08$ & & $2.61 \mathrm{E}-07$ \\
\hline Y91 & $2.11 \mathrm{E}+04$ & $1.37 \mathrm{E}-06$ & & $1.33 \mathrm{E}-06$ & & $1.23 \mathrm{E}-06$ & & $2.20 \mathrm{E}-05$ \\
\hline Zr-95 & $2.70 \mathrm{E}+04$ & $1.75 \mathrm{E}-06$ & & $1.70 \mathrm{E}-06$ & & $1.57 \mathrm{E}-06$ & & $2.81 \mathrm{E}-05$ \\
\hline$\overline{\mathrm{Nb}}-95$ & $4.98 \mathrm{E}+04$ & $3.23 \mathrm{E}-06$ & & $3.14 \mathrm{E}-06$ & & $2.90 \mathrm{E}-06$ & & $5.19 \mathrm{E}-05$ \\
\hline Ru-103 & $5.06 \mathrm{E}+03$ & $3.28 \mathrm{E}-07$ & & $3.19 \mathrm{E}-07$ & & $2.95 \mathrm{E}-07$ & & $5.27 \mathrm{E}-06$ \\
\hline$\overline{R u-106}$ & $2.60 \mathrm{E}+03$ & $1.69 \mathrm{E}-07$ & & $1.64 \mathrm{E}-07$ & & $1.51 \mathrm{E}-07$ & & $2.71 \mathrm{IE}-06$ \\
\hline$\overline{R h}-106$ & $2.60 \mathrm{E}+03$ & $1.69 \mathrm{E}-07$ & & $1.64 \mathrm{E}-07$ & & $1.51 \mathrm{E}-07$ & & $2.71 \mathrm{E}-06$ \\
\hline $\mathrm{Ag}-110$ & $7.09 \mathrm{E}+01$ & $4.60 \mathrm{E}-09$ & & $4.46 \mathrm{E}-09$ & & $4.13 \mathrm{E}-09$ & & $7.38 \mathrm{E}-08$ \\
\hline Sn-123 & $6.84 \mathrm{E}+01$ & $4.44 \mathrm{E}-09$ & & 4.31E-09 & & $3.98 \mathrm{E}-09$ & & $7.12 \mathrm{E}-08$ \\
\hline $\mathbf{S b - 1 2 5}$ & $7.76 \mathrm{E}+01$ & $5.03 \mathrm{E}-09$ & & $4.89 \mathrm{E}-09$ & & $4.52 \mathrm{E}-09$ & & $8.08 \mathrm{E}-08$ \\
\hline $\mathrm{Te}-127$ & $1.23 \mathrm{E}+02$ & $7.98 \mathrm{E}-09$ & & 7.75E-09 & & $7.16 \mathrm{E}-09$ & & $1.28 \mathrm{E}-07$ \\
\hline Te-129 & $1.05 \mathrm{E}+02$ & $6.81 E-09$ & & $6.61 \mathrm{E}-09$ & & 6.11E-09 & & $1.09 \mathrm{E}-07$ \\
\hline Cs-134 & $1.68 \mathrm{E}+03$ & $1.09 \mathrm{E}-07$ & & $1.06 \mathrm{E}-07$ & & $9.78 \mathrm{E}-08$ & & $1.75 \mathrm{E}-06$ \\
\hline$\overline{C s-137}$ & $2.04 \mathrm{E}+03$ & 1.32E-07 & & $1.28 \mathrm{E}-07$ & & $1.19 \mathrm{E}-07$ & & $2.12 \mathrm{E}-06$ \\
\hline $\mathrm{Ce}-141$ & $5.32 \mathrm{E}+03$ & 3.45E-07 & & $3.35 \mathrm{E}-07$ & & $3.10 \mathrm{E}-07$ & & $5.54 \mathrm{E}-06$ \\
\hline Ce-144 & $3.75 \mathrm{E}+04$ & $2.43 \mathrm{E}-06$ & & $2.36 \mathrm{E}-06$ & & $2.18 \mathrm{E}-06$ & & $3.91 \mathrm{E}-05$ \\
\hline Pr-144 & $3.75 \mathrm{E}+04$ & $2.43 \mathrm{E}-06$ & & $2.36 \mathrm{E}-06$ & & $2.18 \mathrm{E}-06$ & & $3.91 \mathrm{E}-05$ \\
\hline Pm-147 & $3.76 \mathrm{E}+03$ & 2.44E-07 & & $2.37 \mathrm{E}-07$ & & $2.19 E-07$ & & $3.92 \mathrm{E}-06$ \\
\hline Pm-148m & $1.03 E+02$ & 6.68E-09 & & 6.49E-09 & & $6.00 \mathrm{E}-09$ & & $1.07 \mathrm{E}-07$ \\
\hline$\overline{E u-155}$ & $4.18 \mathrm{E}+01$ & $2.71 E-09$ & & $2.63 \mathrm{E}-09$ & & $2.43 \mathrm{E}-09$ & & $4.35 \mathrm{E}-08$ \\
\hline U-234 & $1.16 \mathrm{E}-01$ & $7.52 \mathrm{E}-12$ & & $7.30 \mathrm{E}-12$ & & $6.76 \mathrm{E}-12$ & & $1.21 \mathrm{E}-10$ \\
\hline U-235 & $1.01 \mathrm{E}-03$ & 6.55E-14 & & $6.36 \mathrm{E}-14$ & & $5.88 \mathrm{E}-14$ & & $1.05 \mathrm{E}-12$ \\
\hline U-236 & $3.22 \mathrm{E}-02$ & $2.09 \mathrm{E}-12$ & & $2.03 \mathrm{E}-12$ & & $1.88 \mathrm{E}-12$ & & $3.35 \mathrm{E}-11$ \\
\hline U-238 & $8.65 \mathrm{E}-05$ & $5.61 \mathrm{E}-15$ & & 5.45E-15 & & $5.04 \mathrm{E}-15$ & & $9.01 \mathrm{E}-14$ \\
\hline Np-237 & $2.19 \mathrm{E}-02$ & $1.42 \mathrm{E}-12$ & & $1.38 \mathrm{E}-12$ & & $1.28 \mathrm{E}-12$ & & $2.28 \mathrm{E}-11$ \\
\hline Pa-233 & $0.00 \mathrm{E}+00$ & $0.00 \mathrm{E}+00$ & & $0.00 E+00$ & & $0.00 \mathrm{E}+00$ & & $0.00 \mathrm{E}+00$ \\
\hline Pu-238 & $1.02 E+02$ & 6.62E-09 & & $6.42 \mathrm{E}-09$ & & $5.94 \mathrm{E}-09$ & & $1.06 \mathrm{E}-07$ \\
\hline Pu-239 & $4.56 \mathrm{E}-01$ & $2.96 \mathrm{E}-11$ & & $2.87 \mathrm{E}-11$ & & $2.66 \mathrm{E}-11$ & & $4.75 \mathrm{E}-10$ \\
\hline Pu240 & $1.56 \mathrm{E}-01$ & 1.01E-11 & & $9.82 \mathrm{E}-12$ & & $9.08 \mathrm{E}-12$ & & $1.62 \mathrm{E}-10$ \\
\hline Pu-241 & $1.32 \mathrm{E}+02$ & $8.56 \mathrm{E}-09$ & & $8.31 \mathrm{IE}-09$ & & $7.69 \mathrm{E}-09$ & & $1.37 \mathrm{E}-07$ \\
\hline Pu-242 & 1.47E-03 & $9.53 \mathrm{E}-14$ & & $9.26 \mathrm{E}-14$ & & $8.56 \mathrm{E}-14$ & & $1.53 \mathrm{E}-12$ \\
\hline Am-241 & $2.67 \mathrm{E}+00$ & $1.73 \mathrm{E}-10$ & & $1.68 \mathrm{E}-10$ & & $1.55 \mathrm{E}-10$ & & $2.78 \mathrm{E}-09$ \\
\hline Total & 211217.1546665 & 1.37E-05 & & $1.33 \mathrm{E}-05$ & & $1.23 \mathrm{E}-05$ & & $2.20 \mathrm{E}-04$ \\
\hline
\end{tabular}




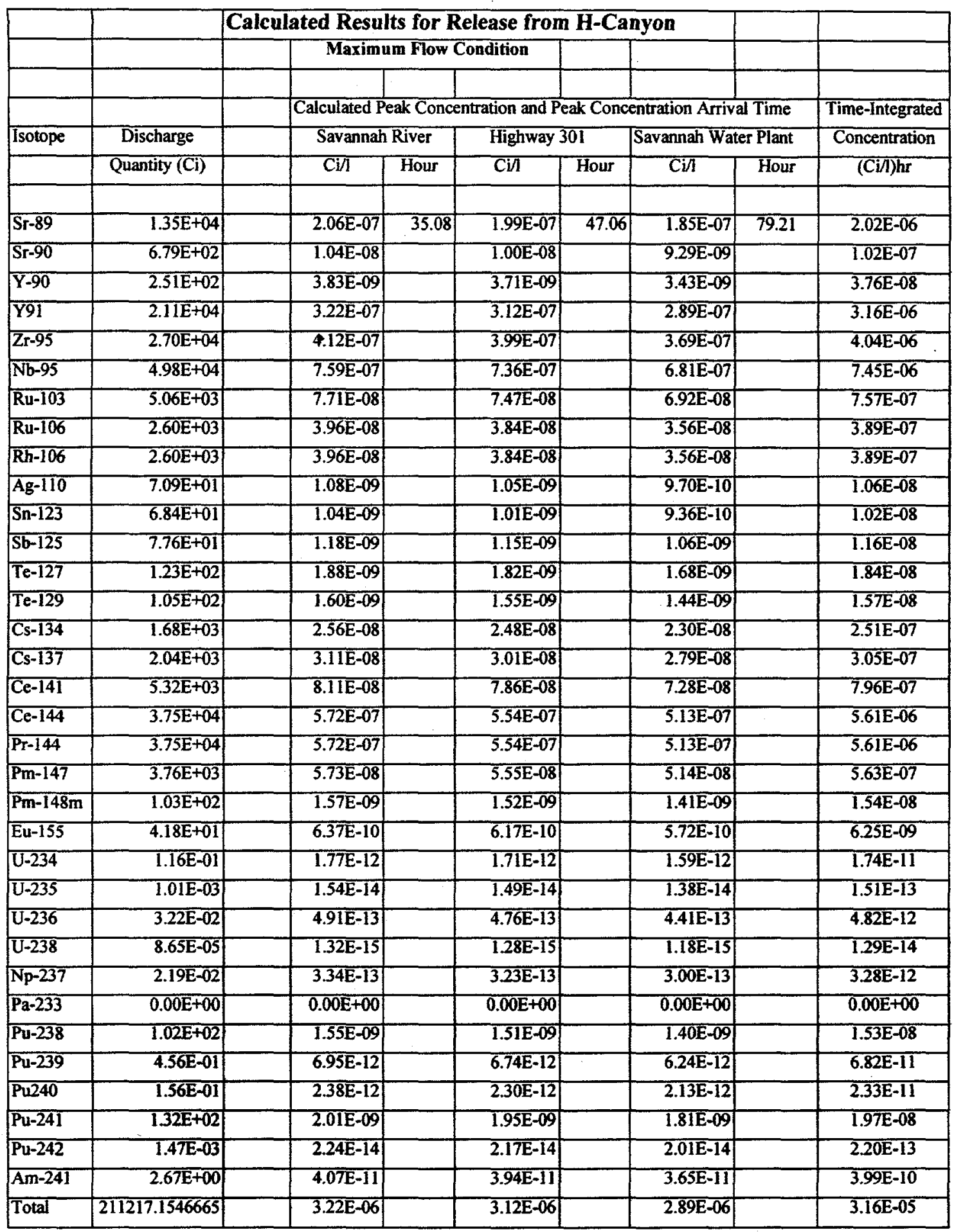


Consequence Analyses Following Potential Savannah River Site Hydrological Releases (U)

WSRC-TR-99-00108

\begin{tabular}{|c|c|c|c|c|c|c|c|c|c|}
\hline \multirow{4}{*}{ Isotope } & \multirow{4}{*}{$\begin{array}{c}\text { Discharge } \\
\text { Quantity (Ci) }\end{array}$} & \multicolumn{7}{|c|}{ Calculated Results for Release from H-Area Tank Farm } & \multirow{4}{*}{$\begin{array}{c}\text { Time-Integrated } \\
\text { Concentration } \\
\text { (Ci/) }) \mathrm{hr}\end{array}$} \\
\hline & & \multirow{3}{*}{\begin{tabular}{|l|} 
Flow \\
Condition \\
\end{tabular}} & \multicolumn{6}{|c|}{ Calculated Peak Concentration and Peak Concentration Arrival Time } & \\
\hline & & & \multicolumn{2}{|c|}{ Savannah River } & \multicolumn{2}{|c|}{ Highway 301} & \multicolumn{2}{|c|}{ Savannah Water Plant } & \\
\hline & & & $\mathrm{Ci} / \mathrm{i}$ & Hour & $\mathrm{Ci} / \mathrm{l}$ & Hour & $\mathrm{Ci} / \mathrm{I}$ & Hour & \\
\hline Sr-90 & $1.20 \mathrm{E}+05$ & Minimum & $1.48 \mathrm{E}-05$ & 111.87 & $1.43 \mathrm{E}-05$ & 140.66 & $1.33 \mathrm{E}-05$ & 219.86 & $4.18 \mathrm{E}-04$ \\
\hline$\overline{R u-106}$ & $1.60 \mathrm{E}+02$ & & $1.97 \mathrm{E}-08$ & & $1.90 \mathrm{E}-08$ & & $1.78 \mathrm{E}-08$ & & $5.57 \mathrm{E}-07$ \\
\hline Cs-134 & $6.50 \mathrm{E}+02$ & & $7.99 \mathrm{E}-08$ & & $7.73 \mathrm{E}-08$ & & $7.22 \mathrm{E}-08$ & & $2.26 \mathrm{E}-06$ \\
\hline Cs-137 & $4.50 \mathrm{E}+03$ & & $5.53 \mathrm{E}-07$ & & $5.35 \mathrm{E}-07$ & & $5.00 \mathrm{E}-07$ & & $1.57 \mathrm{E}-05$ \\
\hline $\mathrm{Ce}-144$ & $4.40 \mathrm{E}+03$ & & 5.41E-07 & & 5.23E-07 & & $4.89 \mathrm{E}-07$ & & $1.53 \mathrm{E}-05$ \\
\hline Pu-238 & $4.20 \mathrm{E}+04$ & & $5.16 \mathrm{E}-06$ & & $5.00 \mathrm{E}-06$ & & $4.66 \mathrm{E}-06$ & & $1.46 \mathrm{E}-04$ \\
\hline Pu-239 & $3.50 \mathrm{E}+01$ & & $4.30 E-09$ & & 4.16E-09 & & $3.89 \mathrm{E}-09$ & & $1.22 E-07$ \\
\hline Pu-240 & $2.60 \mathrm{E}+01$ & & $3.20 \mathrm{E}-09$ & & $3.09 \mathrm{E}-09$ & & $2.89 \mathrm{E}-09$ & & $9.06 \mathrm{E}-08$ \\
\hline Pu-241 & $4.70 \mathrm{E}+03$ & & $5.78 \mathrm{E}-07$ & & $5.59 \mathrm{E}-07$ & & $5.22 \mathrm{E}-07$ & & $1.64 \mathrm{E}-05$ \\
\hline$\overline{A m-241}$ & $4.10 \mathrm{E}+01$ & & $5.04 \mathrm{E}-09$ & & $4.88 \mathrm{E}-09$ & & $4.55 \mathrm{E}-09$ & & $1.43 \mathrm{E}-07$ \\
\hline Total & $1.76512 \mathrm{E}+05$ & & $2.17 \mathrm{E}-05$ & & $2.10 \mathrm{E}-05$ & & $1.96 \mathrm{E}-05$ & & $6.15 E-04$ \\
\hline Sr-90 & $1.20 \mathrm{E}+05$ & Median & $9.59 \mathrm{E}-06$ & 75.37 & $9.25 \mathrm{E}-06$ & $\overline{97.03}$ & $8.57 \mathrm{E}-06$ & 156.50 & $1.67 \mathrm{E}-04$ \\
\hline Ru-106 & $1.60 \mathrm{E}+02$ & & $1.28 \mathrm{E}-08$ & & $1.23 \mathrm{E}-08$ & & $1.14 \mathrm{E}-08$ & & $2.22 \mathrm{E}-07$ \\
\hline Cs-134 & $6.50 \mathrm{E}+02$ & & $5.19 \mathrm{E}-08$ & & $5.01 \mathrm{E}-08$ & & $4.64 \mathrm{E}-08$ & & $9.02 \mathrm{E}-07$ \\
\hline Cs-137 & $4.5 \overline{0 E+03}$ & & $3.59 \mathrm{E}-07$ & & $3.47 \mathrm{E}-07$ & & $3.21 \mathrm{E}-07$ & & $6.25 \mathrm{E}-06$ \\
\hline Ce-144 & $4.40 \mathrm{E}+03$ & & $3.51 E-07$ & & $3.39 \mathrm{E}-07$ & & $3.14 \mathrm{E}-07$ & & $6.11 \mathrm{E}-06$ \\
\hline Pu-238 & $4.20 \mathrm{E}+04$ & & $3.36 \mathrm{E}-06$ & & $3.24 \mathrm{E}-06$ & & $3.00 \mathrm{E}-06$ & & $5.83 \mathrm{E}-05$ \\
\hline Pu-239 & $3.50 \mathrm{E}+01$ & & $2.80 \mathrm{E}-09$ & & $2.70 \mathrm{E}-09$ & & $2.50 \mathrm{E}-09$ & & $4.86 \mathrm{E}-08$ \\
\hline Pu-240 & $2.60 \mathrm{E}+01$ & & $2.08 \mathrm{E}-09$ & & $2.00 \mathrm{E}-09$ & & $1.86 \mathrm{E}-09$ & & $3.61 \mathrm{E}-08$ \\
\hline Pu1-241 & $4.70 \mathrm{E}+03$ & & 3.75E-07 & & $3.62 \mathrm{E}-07$ & & $3.36 \mathrm{E}-07$ & & $6.52 E-06$ \\
\hline Am-241 & $4.10 \mathrm{E}+01$ & & $3.28 \mathrm{E}-09$ & & $3.16 \mathrm{E}-09$ & & $2.93 \mathrm{E}-09$ & & $5.69 \mathrm{E}-08$ \\
\hline Total & $1.76512 \mathrm{E}+05$ & & 1.41E-05 & & $1.36 \mathrm{E}-05$ & & $1.26 \mathrm{E}-05$ & & $2.45 \mathrm{E}-04$ \\
\hline Sr-90 & $1.20 \mathrm{E}+05$ & Mean & $7.75 \mathrm{E}-06$ & 69.16 & $7.55 \mathrm{E}-06$ & 89.32 & $7.00 \mathrm{E}-06$ & 144.07 & $1.25 \mathrm{E}-04$ \\
\hline Ru-106 & $1.60 \mathrm{E}+02$ & & $1.03 \mathrm{E}-08$ & & $1.01 \mathrm{E}-08$ & & $9.34 \mathrm{E}-09$ & & $1.67 \mathrm{E}-07$ \\
\hline Cs-134 & $6.50 \mathrm{E}+02$ & & $4.20 \mathrm{E}-08$ & & $4.09 \mathrm{E}-08$ & & $3.79 \mathrm{E}-08$ & & $6.78 \mathrm{E}-07$ \\
\hline Cs-137 & $4.50 \mathrm{E}+03$ & & 2.91E-07 & & 2.83E-07 & & $2.63 \mathrm{E}-07$ & & $4.69 \mathrm{E}-06$ \\
\hline Ce-144 & $4.40 \mathrm{E}+03$ & & $2.84 \mathrm{E}-07$ & & $2.77 \mathrm{E}-07$ & & $2.57 \mathrm{E}-07$ & & $4.59 \mathrm{E}-06$ \\
\hline Pu-238 & $4.20 \mathrm{E}+04$ & & $2.71 E-06$ & & $2.64 \mathrm{E}-06$ & & $2.45 \mathrm{E}-06$ & & 4.38E-05 \\
\hline Pu-239 & $3.50 \mathrm{E}+01$ & & $2.26 \mathrm{E}-09$ & & $2.20 \mathrm{E}-09$ & & $2.04 \mathrm{E}-09$ & & $3.65 \mathrm{SE}-08$ \\
\hline Pu-240 & $2.60 \mathrm{E}+01$ & & $1.68 \mathrm{E}-09$ & & $1.64 \mathrm{E}-09$ & & $1.52 \mathrm{E}-09$ & & $2.71 E-08$ \\
\hline Pu-241 & $4.70 \mathrm{E}+03$ & & $3.04 \mathrm{E}-07$ & & $2.96 \mathrm{E}-07$ & & 2.74E-07 & & $4.90 \mathrm{E}-06$ \\
\hline Am-24I & $4.10 \mathrm{E}+01$ & & $2.65 \mathrm{E}-09$ & & $2.58 \mathrm{E}-09$ & & $2.39 \mathrm{E}-09$ & & $4.27 \mathrm{E}-08$ \\
\hline Total & $1.76512 \mathrm{E}+05$ & & 1.14E-05 & & 1.11E-05 & & $1.03 \mathrm{E}-05$ & & $1.84 \mathrm{E}-04$ \\
\hline Sr-90 & $1.20 \mathrm{E}+05$ & Maximum & $1.83 \mathrm{E}-06$ & 35.08 & $1.77 \mathrm{E}-06$ & 47.06 & $1.65 \mathrm{E}-06$ & 79.21 & $1.79 E-05$ \\
\hline Ru-106 & $1.60 \mathrm{E}+02$ & & $2.44 \mathrm{E}-09$ & & $2.37 \mathrm{E}-09$ & & $2.19 \mathrm{E}-09$ & & $2.39 \mathrm{E}-08$ \\
\hline Cs-134 & $6.50 \mathrm{E}+02$ & & 9.91E-09 & & $9.61 \mathrm{E}-09$ & & $8.91 \mathrm{E}-09$ & & $9.72 \mathrm{E}-08$ \\
\hline Cs-137 & $4.50 \mathrm{E}+03$ & & $6.86 E-08$ & & $6.65 \mathrm{E}-08$ & & $6.17 \mathrm{E}-08$ & & $6.73 \mathrm{E}-07$ \\
\hline Ce-144 & $4.40 \mathrm{E}+03$ & & $6.71 \mathrm{E}-08$ & & $6.51 \mathrm{E}-08$ & & $6.03 \mathrm{E}-08$ & & $6.58 \mathrm{E}-07$ \\
\hline Pu-238 & $4.20 \mathrm{E}+04$ & & $6.40 \mathrm{E}-07$ & & 6.21E-07 & & $5.76 \mathrm{E}-07$ & & $6.28 E-06$ \\
\hline Pu-239 & $3.50 \mathrm{E}+01$ & & $5.33 \mathrm{E}-10$ & & $5.18 \mathrm{E}-10$ & & $4.80 \mathrm{E}-10$ & & $5.23 \mathrm{E}-09$ \\
\hline Pu-240 & $2.60 \mathrm{E}+01$ & & $3.96 \mathrm{E}-10$ & & $3.84 \mathrm{E}-10$ & & $3.56 \mathrm{E}-10$ & & $3.89 E-09$ \\
\hline Pu-241 & $4.70 E+03$ & & $7.16 \mathrm{E}-08$ & & $6.95 \mathrm{E}-08$ & & $6.44 \mathrm{E}-08$ & & $7.03 E-07$ \\
\hline \begin{tabular}{|l|}
$A \mathrm{Am}-241$ \\
\end{tabular} & $4.10 \mathrm{E}+01$ & & $6.25 \mathrm{E}-10$ & & $6.06 \mathrm{E}-10$ & & $5.62 \mathrm{E}-10$ & & $6.13 \mathrm{E}-09$ \\
\hline Total & $1.76512 \mathrm{E}+05$ & & $2.69 \mathrm{E}-06$ & & $2.61 \mathrm{E}-06$ & & $2.42 \mathrm{E}-06$ & & $2.64 E-05$ \\
\hline
\end{tabular}




\section{ApPendix C Ratios of Radionuclide Concentration to Total Concentration for H-AREA RELEASES}

\begin{tabular}{|c|c|c|c|c|}
\hline \multicolumn{4}{|c|}{ H-Canyon Ratio DILs Calculation Sheet } & \\
\hline \multicolumn{5}{|c|}{$\mathrm{Sr}-90$ is $0.32 \%$ of total Ci concentration } \\
\hline \multicolumn{2}{|c|}{$[\mathrm{Sr}-90] /[$ total $]=0.00322$} & \multicolumn{3}{|c|}{ DIL Sr-90 $=4300 \mathrm{pCi} / \mathrm{L}$} \\
\hline & & & & \\
\hline \multicolumn{5}{|c|}{$[$ DIL Sr-90] $/[$ calculated DIL total] $=0.00322$} \\
\hline & $(\mathrm{pCi} / \mathrm{L})$ & & (pCi/L) & \\
\hline Radionuclide & DIL & $\%$ total [] & DIL total & DIL Ci/L \\
\hline Sr-90 & 4300 & 0.00322 & 1335404 & $1.3354 \mathrm{E}-06$ \\
\hline $1-131$ & 4600 & & & \\
\hline Cs-134 + Cs-137 & 32,000 & $1.76 \mathrm{E}-02$ & 1817476 & $1.81748 \mathrm{E}-06$ \\
\hline Pu-238 + Pu-239 & 54 & $4.98 \mathrm{E}-04$ & 108496.1 & $1.08496 \mathrm{E}-07$ \\
\hline \multicolumn{5}{|l|}{ \&Am-241 } \\
\hline Ru-103 & 183,600 & $2.40 E-02$ & 7658182 & $7.65818 \mathrm{E}-06$ \\
\hline Ru-106 & 12,150 & $1.23 \mathrm{E}-02$ & 987187.5 & $9.87188 \mathrm{E}-07$ \\
\hline Sr-89 & 37,800 & $6.41 \mathrm{E}-02$ & 589680 & $5.8968 \mathrm{E}-07$ \\
\hline $\mathrm{Y}-91$ & 32,400 & $1.00 \mathrm{E}-01$ & 324000 & 0.000000324 \\
\hline Te-132 & 118,800 & & & \\
\hline $1-129$ & 1512 & & & \\
\hline $1-133$ & 189,000 & & & \\
\hline$B a-140$ & 186,300 & & & \\
\hline $\mathrm{Ce}-141$ & 194,400 & $2.52 \mathrm{E}-02$ & 7723192 & $7.72319 \mathrm{E}-06$ \\
\hline Ce-144 & 13,500 & $1.77 \mathrm{E}-01$ & 76120.48 & $7.61205 \mathrm{E}-08$ \\
\hline Np-237 & 108 & $1.04 \mathrm{E}-07$ & $1.04 \mathrm{E}+09$ & $1.0400 \mathrm{E}-03$ \\
\hline Np-239 & 756,000 & & & \\
\hline Pu-241 & 3240 & $6.24 \mathrm{E}-04$ & 5192877 & $5.19288 \mathrm{E}-06$ \\
\hline Zr-95 & 108,000 & $1.28 \mathrm{E}-01$ & 845217.4 & $8.45217 E-07$ \\
\hline $\mathrm{Nb}-95$ & 324,000 & $2.36 \mathrm{E}-01$ & 1373478 & $1.37348 \mathrm{E}-06$ \\
\hline $\mathrm{Cm}-242$ & 513 & & & \\
\hline$\overline{C m-244}$ & 54 & & & \\
\hline
\end{tabular}

\begin{tabular}{|c|c|c|c|c|}
\hline \multicolumn{4}{|c|}{ H-Tank Farm Ratio DILs Calculation Sheet } & \multirow[b]{3}{*}{ in $\mathrm{Ci} / \mathrm{L}$} \\
\hline & pCill & & $\mathrm{pCi} / \mathrm{L}$ & \\
\hline Radionuclide & Rn DIL & $\%$ total & Total DIL & \\
\hline Sr-90 & 4300 & $6.79 \mathrm{E}-01$ & $6.34 \mathrm{E}+03$ & $6.34 \mathrm{E}-0$ \\
\hline Ru-106 & 12,150 & $9.08 \mathrm{E}-04$ & $1.34 \mathrm{E}+07$ & $1.34 \mathrm{E}-05$ \\
\hline Cs-134/137 & 32,000 & $2.92 \mathrm{E}-02$ & $1.10 E+06$ & $1.10 \mathrm{E}-06$ \\
\hline Ce-144 & 13,500 & $2.49 \mathrm{E}-02$ & $5.41 \mathrm{E}+05$ & $5.41 \mathrm{E}-0$ \\
\hline Pu-238/239 + Am 241 & 54 & $2.38 \mathrm{E}-01$ & $2.27 \mathrm{E}+02$ & $2.27 \mathrm{E}-10$ \\
\hline Pu-240 & & & & \\
\hline Pu-241 & 3240 & $2.66 \mathrm{E}-02$ & $1.22 E+05$ & $1.22 \mathrm{E}-07$ \\
\hline
\end{tabular}

